\title{
Hanford Radiological Protection Support Services Annual Report for 1987
}
M. Lyon
J. A. Leonowich
J. J. Fix
H. E. Palmer
J. L. Kenoyer
M. J. Sula

August 1988

Prepared for the U.S. Department of Energy under Contract DE-AC06-76RLO 1830

Pacific Northwest Laboratory

Operated for the U.S. Department of Energy

by Battelle Memorial Institute 


\section{DISCLAIMER}

This report was prepared as an account of work sponsored by an agency of the United States Government. Neither the United States Government nor any agency thereof, nor Battelle Memorial Institute, nor any or their employees, makes any warranty, expressed or implied, or assumes any legal liability or responsibility for the accuracy, completeness, or usefulness of any information, apparatus, product, or process disclosed, or represents that its use would not infringe privately owned rights. Reference herein to any specific commercial product, process, or service by trade name, trademark, manufacturer, or otherwise does not necessarily constitute or imply its endorsement, recommendation, or favoring by the United States Government or any agency thereof, or Battelle Memorial Institute. The views and opinions of authors expressed herein do not necessarily state or reflect those of the United States Government or any agency thereof, or Battelle Memorial Institute.

\section{PACIFIC NORTHWEST LABORATORY operated by \\ BATTELLE MEMORIAL INSTITUTE for the \\ UNITED STATES DEPARTMENT OF ENERGY under Contract DE-AC06-76RLO 1830}

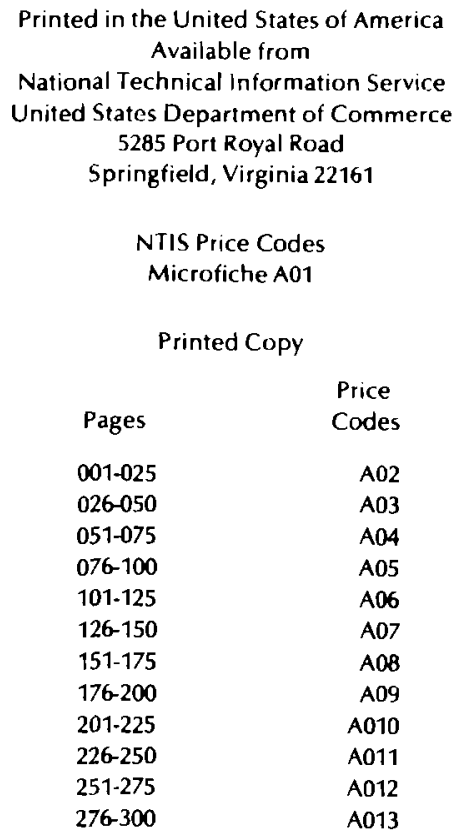


PNL -6624

UC-41

HANFORD RADIOLOGICAL PROTECTION SUPPORT SERVICES ANNUAL REPORT FOR 1987

M. Lyon

J. J. Fix

J. L. Kenoyer

J. A. Leonowich

H. E. Palmer

M. J. Sula

August 1988

Prepared for the U.S. Department of Energy under Contract DE-ACO6-76RLO 1830

Pacific Northwest Laboratory Richland, Washington 99352 


\section{$\underline{\text { SUMMARY }}$}

This report documents the performance of certain radiological protection sitewide services during calendar year (CY) 1987 by Pacific Northwest Laboratory (a) in support of the U.S. Department of Energy-Richland Operations Office (DOE-RL) and contractor activities on the Hanford Site. The routine program for each service is discussed along with any significant program changes and tasks, investigations, and studies performed in support of each program. Other related activities such as publications, presentations, and memberships on standards or industry committees are also discussed. The programs covered provide services in the areas of 1) external dosimetry, 2) internal dosimetry, 3) in vivo measurements, 4) instrument calibration and evaluation, 5) calibration of radiation sources traceable to the National Bureau of Standards, and 6) radiological records.

During 1987 the External Dosimetry Program implemented three new dosimeter capabilities, processed nearly 10,000 quality control dosimeters, and conducted six technical studies in support of sitewide dosimeter processing. These studies included long-term dosimeter fading, abnormal glow curves for ring dosimeters, rounding recorded doses to multiples of 10 , and biases in 1987 basic dosimeter results. Also, studies involving documentation of dosimeter lower level of detection and angular response were performed in preparation for performance testing by the Department of Energy Laboratory Accreditation Program (DOELAP). Three policies involving abnormal dosimeter results, skin dose assessment, and supplemental dosimeter use were formally adopted following their review by the Hanford Personnel Dosimetry Advisory Committee. The program manual was completely revised and distributed. Numerous internal technical reports were prepared, which address several technical issues involving DOELAP requirements, DOE 5480.11(b) requirements, and operational considerations.

(a) Pacific Northwest Laboratory is operated for the U.S. Department of Energy by Battelle Memorial Institute under Contract DE-ACO6-76RLO 1830.

(b) U.S. Department of Energy (DOE). 1987. Radiation Protection for Occupational Workers. Draft DOE 5480.11, U.S. Department of Energy, Washington, D.C. 
Under the Internal Dosimetry Program, 13,144 routine, 113 supplemental, and 281 retrospective bioassay measurements were performed in 1987 . Fourteen potential internal incidents involving 20 workers were reported. Internal dose assessments were performed and documented for 135 cases where potential internal exposure was investigated. Quality control monitoring of the bioassay analytical services laboratory continued with generally satisfactory results, and the laboratory Statement of Work was revised to reflect new criteria and methods. Supporting tasks performed included the development of an internal dose database (called INTERTRAC) and an educational videotape. To improve technical capability, a pilot fecal sampling and analysis program was conducted, portable wound survey instruments were procured for use at the Emergency Decontamination Facility (EDF), and an internal exposure sources catalog was prepared. Several special internal dosimetry assessments were completed.

The In Vivo Measurements Program provided 10,174 measurements in 1987. Changes to equipment and facilities during the year included removing an old mobile whole body counter (WBC) from service, upgrading the WBC facilities at the EDF, acquiring a new multichannel analyzer system, installing new audio and visual communications systems in the shielded rooms, and procuring several new germanium detectors. Special studies performed to improve the accuracy and sensitivity of the measurements included documentation of the WBC calibration data, measurement of a person with a known deposition of $133 \mathrm{Ba}$, construction of realistic phantoms to be used for calibrations of the WBC, and reduction of external contamination on employees arriving for counting.

Specific tasks performed under the Instrument Calibration and Evaluation Program during CY 1987 included the Routine Portable Instrument Pool, the Hanford Instrument Evaluation Program, Deployment of High-Range Cutie Pies, Instrument Manual Update, and the Documentation of the History of Hanford Instruments. Tasks performed during the year that supported the routine program included upgrading the calibration procedure for the alpha continuous air monitors, designing and fabricating new beta source holders to replace the fan source holder, and upgrading the present special nuclear material (SNM) portable monitors as well as evaluating new SNM monitors. 
The Radiation Standards and Calibration Project maintains radiological standards, special instrument and dosimeter response-characterizing equipment, and calibration data handling equipment at Hanford. The project is divided into two major functions: maintenance of standards and capabilities and maintenance of the data management systems. Improvements to the project included installing a new 60Co source in the source transfer system, developing an improved calibration protocol for neutron measuring instruments, and designing and installing an attenuator mechanism for photon source we 113 . A major improvement in the data management system was the replacement of the old computer with an HP-9000 as well as a number of software upgrades. Supporting investigations and studies conducted during 1987 included measurement quality assurance for photon beams and $90 \mathrm{Sr}$ betas, intercomparison of $k$-fluorescence standards, source travel time, plutonium-lithium source calibration, and an evaluation of instrument bar code label.

During the year, the Radiological Records Program operated the Occupational Radiation Exposure (ORE) system and Hanford Radiation Protection Historical Files in support of the DOE-RL and Hanford contractor radiological protection and dosimetry programs. Changes to these systems included adding special dosimeter processing forms in the individuals' records and incorporating enhanced quality control methodology. Tasks performed in support of the program included the multitude of changes needed for the Hanford consolidation project and modification of the ORE system to accept supplemental dosimeter results keyed to specific body locations and to accept the results of two new types of dosimeters. An ORE users group was formed to provide closer contact between program personnel and the contractors. 


\section{ACKNOWLEDGMENTS}

The authors thank the staff members whose professional skills and technical expertise ensure the success of Hanford's External Dosimetry Program, Internal Dosimetry Program, In Vivo Measurement Program, Instrument Calibration and Evaluation Program, Radiation Standards and Calibrations Project, and Radiological Records Program. 


\section{CONTENTS}

SUMMARY ........................... . . . i i i

ACKNOWLEDGMENTS ....................... . . . vii

ACRONYMS ............................ X XV

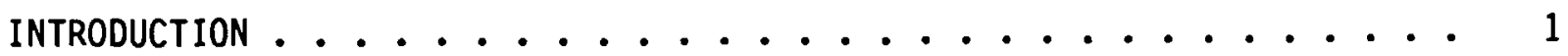

HANFORD EXTERNAL DOSIMETRY PROGRAM . . . . . . . . . . . . . 3

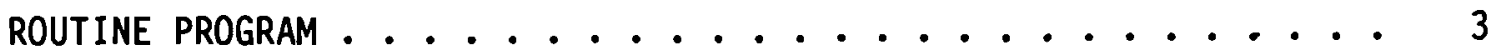

Abnormal Dosimeter Results ............. 6

Skin Dose Assessment ............... 6

Supplemental Dosimeter ................ 7

SUPPORTING INVESTIGATIONS AND STUDIES . . . . . . . . . . . 7

Evaluation of Long-Term Dosimeter Fading . . . . . . . . 7

Investigation of Abnormal Glow Curves for Ring Dosimeters • . '8

Rounding Recorded Doses to Multiples of $10 \mathrm{mrem}$. . . . . 8

Determination of Angular Response . . . . . . . . . 9

Determination of Lower Level of Detection for Dosimeters . . . 10

Bias in 1987 Basic Dosimeter Results . . . . . . . . 10

PUBLICATIONS . . . . . . . . . . . . . . 13

EXTERNAL PROFESSIONAL ACTIVITIES . . . . . . . . . . . 14

HANFORD INTERNAL DOSIMETRY PROGRAM . . . . . . . . . . . . . 17

ROUTINE PROGRAM ..................... 17

MONITORING AND ASSESSMENT ACTIVITIES . . . . . . . . . . . 21

BIOASSAY ANALYTICAL SERVICES . . . . . . . . . . . 25

Changes to the Statement of Work ............ 25

Quality Control--United States Testing Company, Inc. . . . . 25

Quality Control--External Audit Sample Program . . . . . . 26 
Sequential $90 \mathrm{Sr}, 144 \mathrm{Ce}, 147 \mathrm{Pm}$ Urinalysis ........ 27 SUPPORTING INVESTIGATIONS AND STUDIES ............ 27

Upgrades Supporting Implementation of DOE $5480.11 \ldots 28$

Development of an Educational Videotape ....... 28 SPECIAL INTERNAL DOSIMETRY ASSESSMENTS ........... 29

Status of a 1985 Plutonium-Contaminated Wound Case . . . . 29

Final Update on H.R. MCCluskey Bioassay Measurements .... 30

Measurement of Chernobyl-Related Radionuclides in Hanford

Workers ................. 30

IMPROVEMENTS IN TECHNICAL CAPABILITY ........... 31

Pilot Fecal Sampling and Analysis Program ........ 31

Implementation of Portable Wound Survey Instruments . . . . 31

Internal Exposure Sources Catalog .......... 32

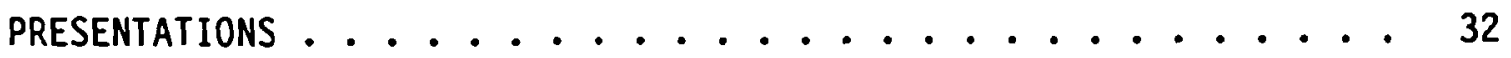

EXTERNAL PROFESSIONAL ACTIVITIES ............ 32

HANFORD IN VIVO MEASUREMENT PROGRAM ............... 33

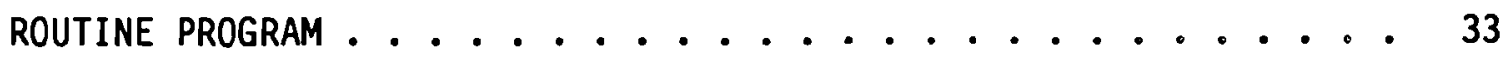

ADDITIONS OR CHANGES TO EQUIPMENT AND FACILITIES IN $1987 \ldots 35$

Mobile Whole Body Counter B Removed from Service . . . . . 35

Upgrade of Whole Body Counting Facilities

at the Emergency Decontamination Facility ........ 36

New Shielded Rooms ............... 36

Design of a New Mobile Whole Body Counter ....... 37

New Multichannel Analyzer System . . . . . . . . . 37

New Audio-Visual Communication Systems

for the Shielded Rooms ............. 37

New Detector Systems . . . . . . . . . . . 38 
SPECIAL STUDIES CONDUCTED DURING $1987 \ldots \ldots . \ldots . \ldots$

Documentation of Whole Body Counting Calibration Data ... 38

Measurement of a Person Containing a Known Amount of 133Ba . 40

Skeletal Phantoms for Estimating $241_{\text {Am }}$ in Bone ....... 40

Reduction of External Contamination on the Skin and

Clothing of Employees ........................ 43

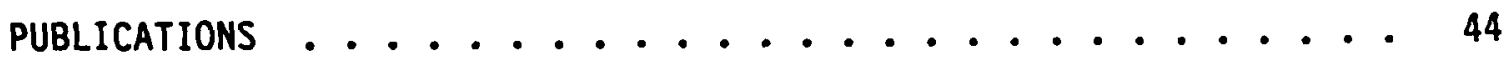

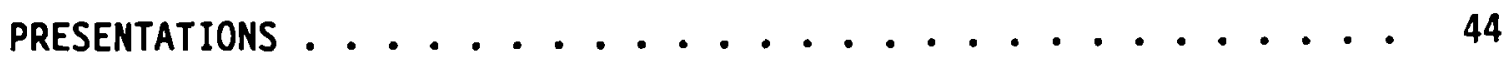

INSTRUMENT CALIBRATION AND EVALUATION PROGRAM ............ 47

ROUTINE PROGRAM .............................. 48

Routine Portable Instrument Pool ........... 48

Hanford Instrument Evaluation Program ......... 48

Deployment of High-Range CPs ............ 50

Instrument Manual Update .............. 51

Documentation of the History of Hanford Instruments .... 52

SUPPORTING INVESTIGATION AND STUDIES ............ 52

Upgrade of the Alpha CAM Calibration Procedures ...... 52

Development of the Linear Beta Source Concept and Design ... 53

Upgrade of the Special Nuclear Material Portable Monitors . . 53

PROGRAM-RELATED PROFESSIONAL MEMBERSHIPS .......... 53

RADIATION STANDARDS AND CALIBRATIONS PROJECT . . . . . . . . 55

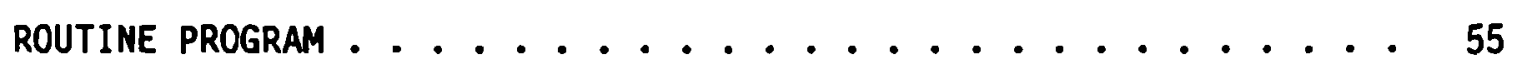

Maintenance of Standards and Capabilities ........ 55

Maintenance of the Data Management System . . . . . 57

SUPPORTING INVESTIGATIONS AND STUDIES ........... 58

Measurement Quality Assurance for Photon Beams and $90 \mathrm{Sr}$

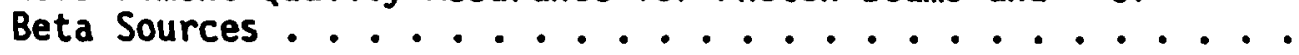


Intercomparison of K-Fluorescence Standards ....... 58

Source Travel Time Study............... 59

Plutonium-Lithium Source Calibration ......... 59

Evaluation of Instrument Bar Code Labels . . . . . . 59

HANFORD RADIOLOGICAL RECORDS PROGRAM .............. 61

ROUTINE PROGRAM .......................... 61

Changes to the Routine Program ............ 63

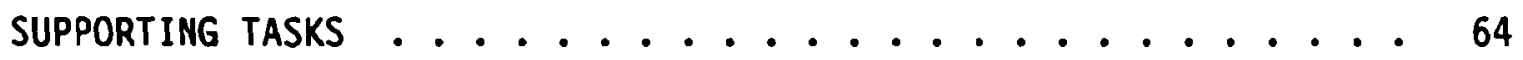

Changes Made to Accommodate Hanford Contractor Consolidation . 64

Modifications to the ORE System--Specific Body Locations

and New Dos imeter Types ............. 66

Hanford Dosimetry Computer Integration Committee ..... 66

REFERENCES ..................... 67 


\section{FIGURES}

1 Major Communication Interfaces of the Hanford Radiological Support Services ........... 2

2 New Dosimeters Incorporated into the Routine External Dosimetry Program During 1987 . . . . . . . 4

3 Angular Response of the Hanford Multipurpose Dosimeter ..... 10

4 Distribution of Year-End Basic Dosimeter Results . . . . . . 12

5 In Vivo Measurements Taken at the Hanford Whole Body Counter Facilities, 1977 Through $1987 \ldots . . . . . . .35$

6 Installation and Upgrade of Two Whole Body Counters at the Emergency Decontamination Facility ........ 36

7 Array of Six Detectors for the Second Lung Counter . . . . . 39

8 Calibration Curve for Two 51-mm-Diameter by 20-mm-Thick Detectors Located on the Forehead ............. 41

9 Head, Leg, and Arm Phantoms Constructed of Tissue-Equivalent Polyurethane ............ 42

10 High-Range $C P \ldots \ldots . \ldots \ldots$ 


\section{$\underline{\text { TABLES }}$}

1 Audit Dosimeters Processed During $1987 \ldots \ldots$. . . . . . 5

2 Lower Levels of Detection for Hanford Dosimeters . . . . . . 11

3 Minimum Detectable Activities and Follow-Up

Levels for Routine Urinalyses During 1987 . . . . . . . . 19

4 Minimum Detectable Activities and Follow-Up

Levels for In Vivo Measurements During 1987 . . . . . . 20

5 Models Used to Interpret Bioassay Data During $1987 \ldots 21$

6 Routine Urinalyses Performed During $1987 \ldots 22$

7 Routine In Vivo Measurements Performed During $1987 \ldots 22$

8 Summary of Potential Internal Exposure Incidents During $1987 \ldots \ldots 23$

9 Internal Dose Status of Hanford Workforce at 1987 Year-End . . 24

10 In Vivo Measurements Made During 1987 . . . . . . . . . 34

11 Portable Instrument Usage for Calendar Year $1987 \ldots 49$

12 Records Activity for Calendar Year 1987 ........... 63 
ACRONYMS

$\begin{array}{ll}\text { ALARA } & \text { as low as reasonably achievable } \\ \text { ANSI } & \text { American National Standards Institute } \\ \text { BCSR } & \text { Boeing Computer Services-Richland } \\ \text { CAM } & \text { continuous air monitor } \\ \text { CAR } & \text { computer-assisted retrieval } \\ \text { CP } & \text { ion chamber radiation instrument called "Cutie Pie" } \\ \text { CSF } & \text { chip sensitivity factor } \\ \text { CY } & \text { calendar year } \\ \text { DOE } & \text { U.S. Department of Energy } \\ \text { DOELAP } & \text { Department of Energy Laboratory Accreditation Program } \\ \text { EDF } & \text { Emergency Decontamination Facility } \\ \text { FY } & \text { fiscal year } \\ \text { GI } & \text { gastrointestinal } \\ \text { HEDL } & \text { Hanford Engineering Development Laboratory } \\ \text { HEHF } & \text { Hanford Environmental Health Foundation } \\ \text { HPS } & \text { Health Physics Society } \\ \text { HPSSC } & \text { Health Physics Society Standards Committee } \\ \text { HP } & \text { Hewlett Packard } \\ \text { HQ } & \text { headquarters } \\ \text { HRCP } & \text { high-range CP } \\ \text { ICRP } & \text { International Commission for Radiological Protection } \\ \text { I\&ED } & \text { Instrumentation and External Dosimetry } \\ \text { JAJ } & \text { J. A. Jones Construction Services Company } \\ \text { KEH } & \text { Kaiser Engineers Hanford } \\ \text { MDA } & \text { minimum detectable activity } \\ \text { MPBB } & \text { maximum permissible body burden } \\ \text { MQA } & \text { measurement quality assurance } \\ \text { NBS } & \text { National Bureau of Standards } \\ \text { NRPB } & \text { National Radiological Protection Board } \\ \text { ORE } & \text { occupational radiation exposure } \\ \text { PNL } & \text { Pacific Northwest Laboratory } \\ \text { QC } & \text { quality control } \\ \text { Rockwell Hanford Operations }\end{array}$


RL Richland Operations Office

RPS radiation protection standard

SEE specific effective energy

SNM special nuclear material

UNC UNC Nuclear Industries

UST United States Testing Company, Inc.

USTR United States Transuranium Registry

WBC whole body counter

WHC Westinghouse Hanford Company 


\section{INTRODUCTION}

This annual report documents the calendar year (CY) 1987 activities of certain sitewide services operated by the Pacific Northwest Laboratory (PNL) for the U.S. Department of Energy-Richland Operations Office (DOE-RL) and the Hanford contractors. The programs covered provide services in the areas of 1) external dosimetry, 2) internal dosimetry, 3) in vivo measurements, 4) instrument calibration and evaluation, 5) calibration of radiation sources traceable to the National Bureau of Standards (NBS), and 6) radiological records. All of the services fall within the purview of PNL's Health Physics Department.

While some of the programs discussed in this report are involved in activities funded by other sources such as supplying in vivo measurement and instrument calibration services to private nuclear companies and site environmental dose measurements, only those activities funded by DOE-RL and the Hanford contractors are addressed. It should be noted that 1) the services provided to non-DOE-RL activities are performed only to the extent that they do not affect services to DOE and its contractors, and 2) these services provide funds that support the program and reduce the costs to DOE and the Hanford contractors (i.e., Boeing Computer Services-Richland [BSCR], J. A. Jones Construction Services Company [JAJ], Kaiser Engineers Hanford [KEH], Rockwell Hanford Operations [RHO], UNC Nuclear Industries [UNC], Westinghouse Hanford Company [WHC], and PNL).

Each Hanford program listed above is presented in a separate section of the report, which discusses the routine program, including any significant changes; investigations, studies, and tasks performed in support of the routine program; and other applicable activities such as publications, presentations, program-related professional memberships, and related external professional activities. Figure 1 is an organizational chart showing the PNL and DOE management structure and communication interfaces for each PNLoperated program and the DOE Safety and Environment Division. 


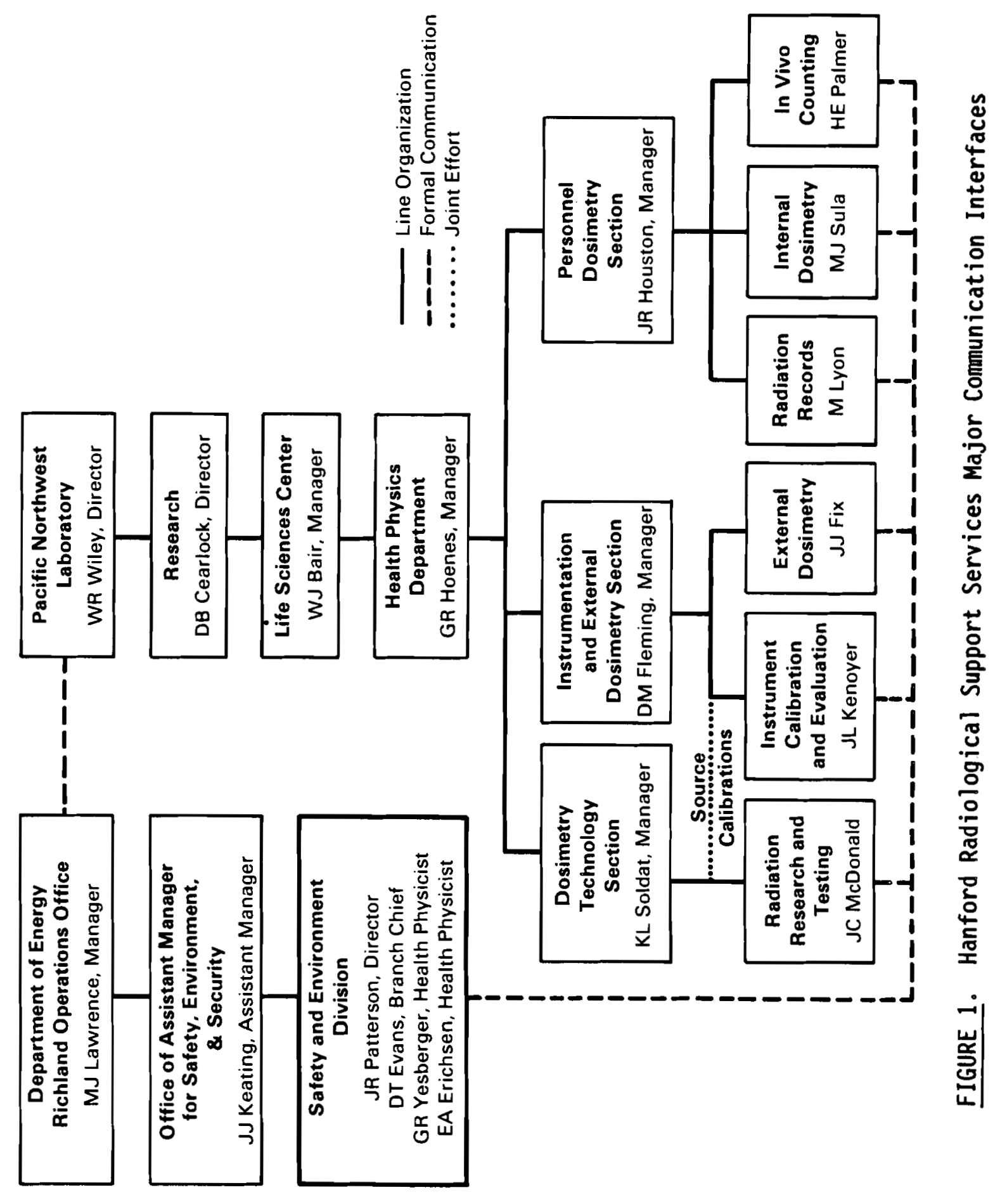


The Hanford External Dosimetry Program is a multifaceted effort involving all Hanford contractors. Dose-of-record information from external radiation for Hanford personnel is provided by this program in compliance with the requirements of DOE 5480.1 (DOE 1981a), DOE 5480.15 (DOE 1987) and RL 5480.11A (RL 1986). Program dosimeter services provide the means used by contractor personnel to project, control, and measure radiation doses received by personnel. Program staff also provide sitewide nuclear accident dosimetry in compliance with DOE 5480.1 requirements and penetrating radiation environmental measurements in support of Hanford Environmental Surveillance Program tasks necessary to meet DOE 5484.1 (DOE 1981b) requirements. Program activities during 1987 are discussed in the following subsections.

\section{ROUTINE PROGRAM}

Three new dosimeters were incorporated into the routine program during 1987 (see Figure 2):

- two-element supplemental dosimeter

- beta/photon personnel dosimeter

- multi-element area dosimeter.

A relatively small injection-molded two-element dosimeter was developed to provide supplemental monitoring capabilities for workers potentially exposed to nonuniform fields of radiation. The shielding on this dosimeter is nearly identical to the shielding in positions one and two of the multipurpose dosimeter. A beta/photon personnel dosimeter was developed during the year for use in employee work environments where beta radiation contributes a significant fraction of the dose received. This dosimeter would be worn in addition to the multipurpose dosimeter, which includes the security credential. A multi-element area dosimeter that provides a sensitive measure of the beta and photon energy spectrum and intensity in the work environments was developed. The measurements from this dosimeter are used to characterize the radiation fields in Hanford work environments. This information is used to determine if the proper personnel dosimeter and calibration factors are being used. 


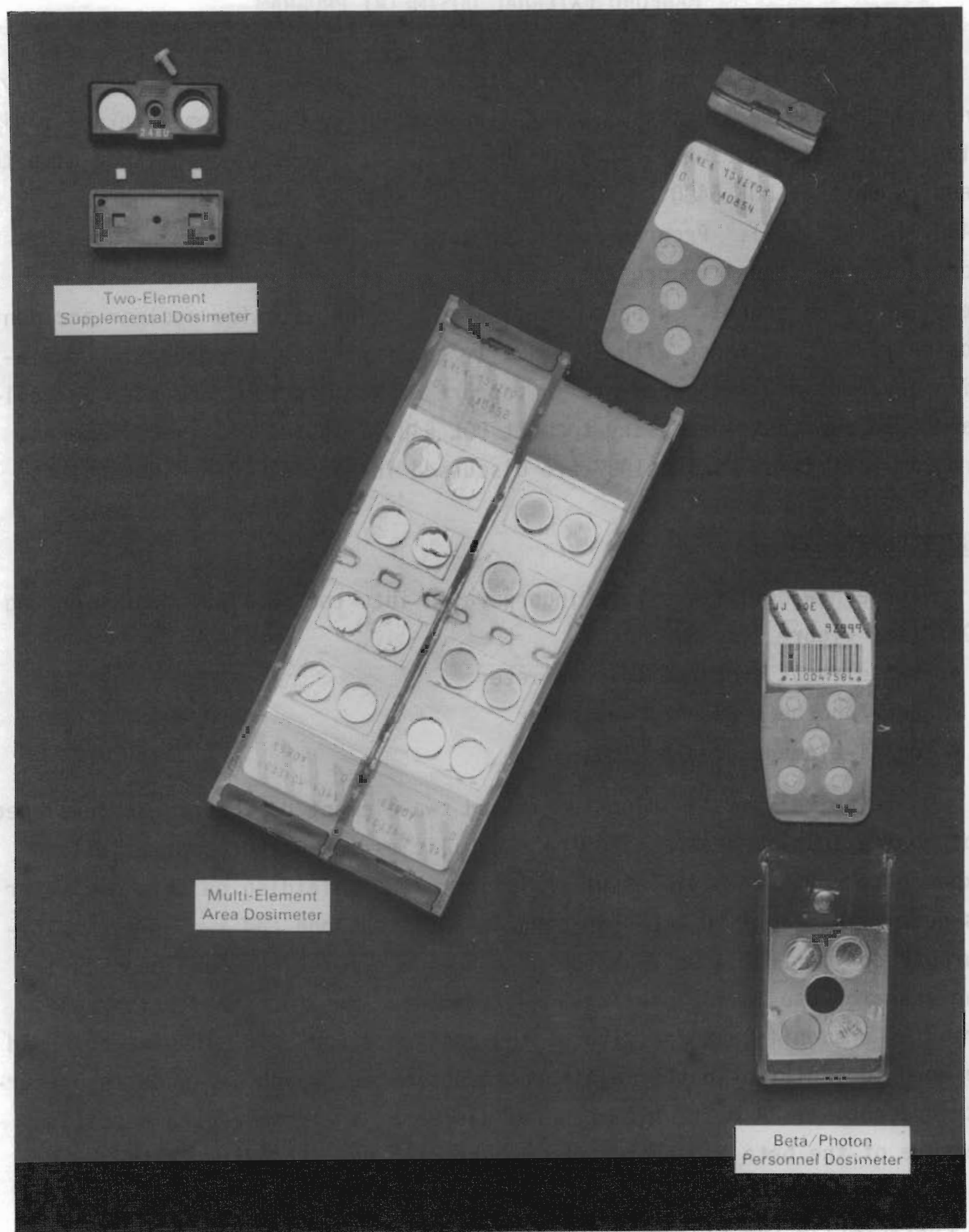

FIGURE 2. New Dosimeters Incorporated into the Routine External Dosimetry Program During 1987 
Algorithm and calibration changes were made in anticipation of Hanford's participation in selected categories of the Department of Energy Laboratory Accreditation Program (DOELAP) for personnel dosimetry. In particular, a new algorithm for Hanford basic and multipurpose personnel dosimeters was implemented. The use of $16-\mathrm{keV}$ k-fluorescent radiation was implemented for calibration of the shallow dose determination for Hanford two-element, beta/photon, and multipurpose dosimeters.

Each year numerous control and audit dosimeters are processed to assess the integrity of the dosimeter processing. During 1987, 4269 control dosimeters and 3815 audit dosimeters were processed. A breakdown of the audit dosimeters is shown in Table 1.

Control charts are used to evaluate the results for each of the audit dosimeter categories. Charts are prepared for each type of dosimeter and radiation for each of the 17 dosimeter processing runs (monthly, quarterly, and annual) conducted each year. A quality control report is prepared for each processing. Copies of the report are distributed to all Hanford contractor radiation protection organizations and to the Hanford Radiation Protection Historical Files. Copies of the control charts are also submitted to the historical files.

TABLE 1. Audit Dosimeters Processed During 1987

\begin{tabular}{|c|c|c|c|c|c|c|}
\hline \multirow[b]{2}{*}{ Dosimeter } & \multicolumn{6}{|c|}{ Dose Category(a) } \\
\hline & Shallow & Deep & Fast Neutron & slow & Neutron & Blank \\
\hline Basic & NA & 366 & NA & & NA & 170 \\
\hline Multipurpose & 765 & 823 & 492 & & 389 & 170 \\
\hline Rings & NA & 340 & NA & & NA & Controls \\
\hline Two-e lement & 150 & 150 & NA & & NA & Controls \\
\hline
\end{tabular}

(a) $\mathrm{NA}=$ not applicable. 
During 1987 Hanford practices were adopted for the following:

- flagging abnormal dosimeter results (notecode 50)

- assessment of skin dose

- supplemental dosimetry.

The three practices were approved by the Hanford Personnel Dosimetry Advisory Committee. The practice adopted for each of these areas is summarized in the following subsections.

\section{Abnormal Dosimeter Results}

Occasionally, the results from processing a dosimeter are incorrect. This may be evident from the glow curve or from the relationship between the chip counts. A formal policy was adopted where External Dosimetry staff identify these dosimeters with a notecode 50 . The respective contractor is notified whenever the notecode is used. With this notecode the dosimeter results are not automatically reported to the field or recorded in the individual dose record. Instead, the dosimeter results are included in an audit file. To remove the results from this file and have the dose recorded in the occupational radiation exposure (ORE) database, the respective contractor must prepare a letter to either verify that the dosimeter results are accurate or provide the estimated dose to be recorded based on a field investigation. (a)

\section{$\underline{\text { Skin Dose Assessment }}$}

A standard practice to determine skin dose from contaminated skin or clothing was adopted. The practice is based on the dose factors included in NUREG/CR-4418 (Traub et al. 1987). Unless case-specific information is available, the assumptions used in this practice include the following:

- an instrument detection efficiency of $12 \%$

- an area of contamination equal to the pancake survey instrument probe area $\left(15.5 \mathrm{~cm}^{2}\right)$

- a negligible dose contribution from gamma rays.

(a) Fix, J. J. 1987. "Proposed Practice for Handling Abnormal Dosimeter Results." Letter to Distribution, dated August 24, 1987, Hanford Radiation Protection Historical Files, Pacific Northwest Laboratory, Richland, Washington. 
For each assessment, a written evaluation is submitted to Radiological Records for filing in the individual's exposure record. The dose assessed to specific areas of the skin from contamination is not included in the skin dose recorded from the personnel dosimeter results.(a)

\section{Supplemental Dosimeter}

A practice was adopted for wearing the record personnel dosimeter and for the use of supplemental dosimeters. An individual's record dosimeter shall always be worn on the front of the torso between the waist and the neck. Dosimeters accredited by DOELAP shall be used for supplemental dosimetry whenever possible. In those instances where the use of the personnel dosimeters is not practical, a technical evaluation shall be conducted to determine which dosimeter is the appropriate one to use. This evaluation may result in the use of the two-element dosimeter. Small multipurpose dosimeter holders were procured for use with supplemental dosimeters. (a)

\section{SUPPORTING INVESTIGATIONS AND STUDIES}

Studies were conducted during 1987 to upgrade program documentation, resolve technical issues, and improve quality control of dosimeter fabrication, use, processing, or dose assessment. These studies are discussed in the following subsections.

\section{Evaluation of Long-Term Dosimeter Fading}

For the past 3 years, six sets of audit multipurpose dosimeters have been exposed and retained for year-end processing to determine the significance of long-term dosimeter fading and environmental radiation accumulation. The evaluation has been complicated because of the variability in the data from year to year. Each set of dosimeters is composed of the following:

(a) Fix, J. J. 1987. "Minutes of Hanford Personnel Dosimetry Advisory Committee Meeting on December 9, 1987." Letter to Distribution, dated December 23, 1987, Hanford Radiation Protection Historical Files, Pacific Northwest Laboratory, Richland, Washington. 
- 10 dosimeters exposed to $1000 \mathrm{mR}$ of $137 \mathrm{Cs}$ gamma radiation

- 10 dosimeters exposed to 2000 mrad of U-nat radiation

- 6 dosimeters exposed to $1000 \mathrm{mrem}$ of $252 \mathrm{Cf}$ fast neutron radiation

- 6 dosimeters exposed to 50 mrem of sigma pile thermal neutron radiation

- 10 dosimeters with no exposure.

During 1987 a set of dosimeters was exposed on the following dates:

$\begin{array}{ll}\text { January } 30 & \text { February } 27 \\ \text { April } 24 & \text { June } 26 \\ \text { September } 25 & \text { November } 27\end{array}$

All dosimeters were processed with the annual run during January 1988 . The environmental penetrating dose in the Hanford environs is expected to average about $70 \mathrm{mrad} / \mathrm{yr}$ as determined from historical environmental dosimeter measurements. The results from these dosimeters show a contribution of between 30 and $60 \mathrm{mrem} / \mathrm{yr}$ to the dose results for annually exchanged dosimeters from environmental background radiation. Presently, dosimeter dose components are adjusted for the expected dose from background radiation based on the time elapsed between the most recent two processings. The correction for a 1-year period is equivalent to an annual dose of $57 \mathrm{mrem} / \mathrm{yr}$.

Investigation of Abnormal Glow Curves for Ring Dosimeters

Beginning in February 1987, the glow curves for the ring dosimeters showed an abnormal structure. The cause of the change was not apparent. After several tests of the chips and the reader systems, it was concluded that an invisible contaminant was present on new ring casings that had been introduced into the pool. Although identical in appearance to the rings used since October 1986, upon investigation these rings were determined to be manufactured in an automated system that required the use of a lubricant during molding. The problem was solved by requiring an alcohol rinse of all ring casings prior to each use.

Rounding Recorded Doses to Multiples of $10 \mathrm{mrem}$

An assessment of the procedure used to round recorded doses at Hanford to multiples of 10 mrem was conducted in response to an outside technical 
appraisal done during August 1984. Findings were reported to the Personnel Dosimetry Advisory Committee. (a) No significance was observed between annual doses based on dosimeter results, calculated to the nearest whole number or to the nearest multiple of 10 mrem for individuals. No significant difference was observed for cumulative doses per contractor with the exception of the slow neutron dose category. This resulted from the summation of many, small, slow neutron doses of less than 5 mrem (i.e., doses are reported if they are 0.5 centirem or greater because of the practice of adding 0.5 centirem to each dose category before truncation and multiplication by a factor of 10 to arrive at the millirem dose). These slow neutron doses are an insignificant addition to the fast neutron dose and deep dose that is currently calculated. The committee decided to continue with the historical Hanford practice, which was determined to result in a more realistic representation of the measured doses.

Determination of Angular Response

The angular response of Hanford basic, multipurpose, and beta/photon personnel dosimeters was determined. This information is required by $D O E$ 5480.15 (DOE 1987) for participation in DOELAP. Dosimeters were exposed to several different radiation sources and seven angles ranging from -85 to +85 degrees. Radiation sources included the following: $90 \mathrm{Sr}$ M30 filtered $x$ ray

$16 \mathrm{keV} k$-fluroescent $x$ ray M150 filtered $x$ ray $59 \mathrm{keV} k$-fluorescent $x$ ray 252Cf (unmoderated) $252 \mathrm{Cf}$ (moderated) 137 Cs

Figure 3 shows an example of the response characteristics observed for the multipurpose dosimeter. The data for $137 \mathrm{Cs}$ gamma, 252Cf (unmoderated), 59-keV k-fluorescent, and 16-keV k-fluorescent radiation are shown. The lack of symmetry is due to the location of the chips in the dosimeter.

(a) Fix, J. J. 1987. "Information Pertaining to Hanford Method of Personnel Dosimeter Dose Reporting." Letter to Distribution, dated June 24, 1987, Hanford Radiation Protection Historical Files, Pacific Northwest Laboratory, Richland, Washington. 


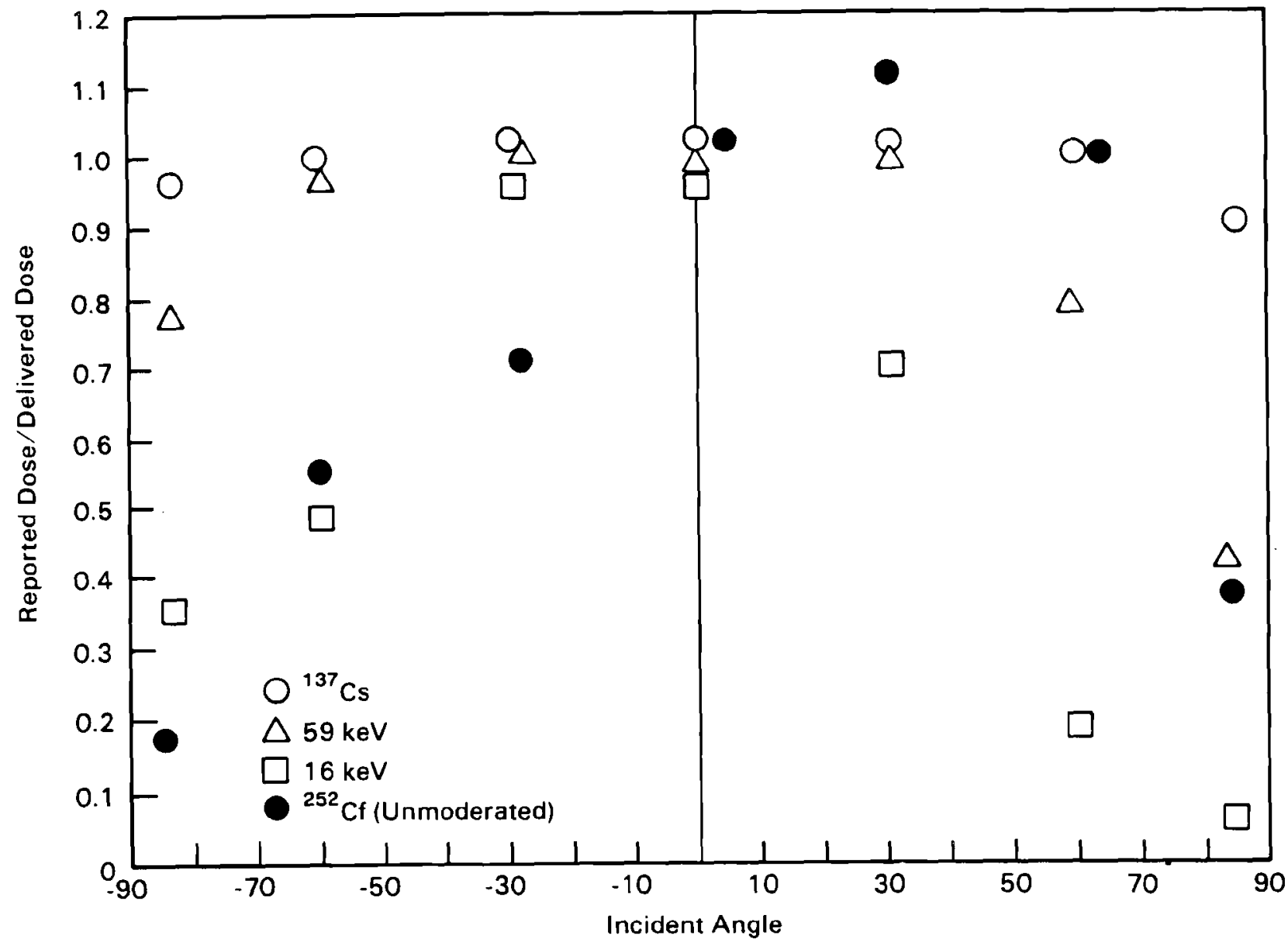

FIGURE 3. Angular Response of the Hanford Multipurpose Dosimeter

\section{Determination of Lower Level of Detection for Dosimeters}

The lower level of detection of Hanford basic, multipurpose, and beta/ photon personnel dosimeters was determined as specified in DOE 5480.15 (DOE 1987). This information is also necessary for participation in the DOELAP program. Table 2 lists the lower detection levels for the dosimeters.

\section{Bias in 1987 Basic Dosimeter Results}

A positive bias of approximately $10 \mathrm{mrem}$ was observed in the reported results for annually exchanged basic dosimeters. These dosimeters are generally used by personnel who are not anticipated to receive significant external exposure. Prior to adopting the policy during the spring of 1987 to 
TABLE 2. Lower Levels of Detection for Hanford Dosimeters

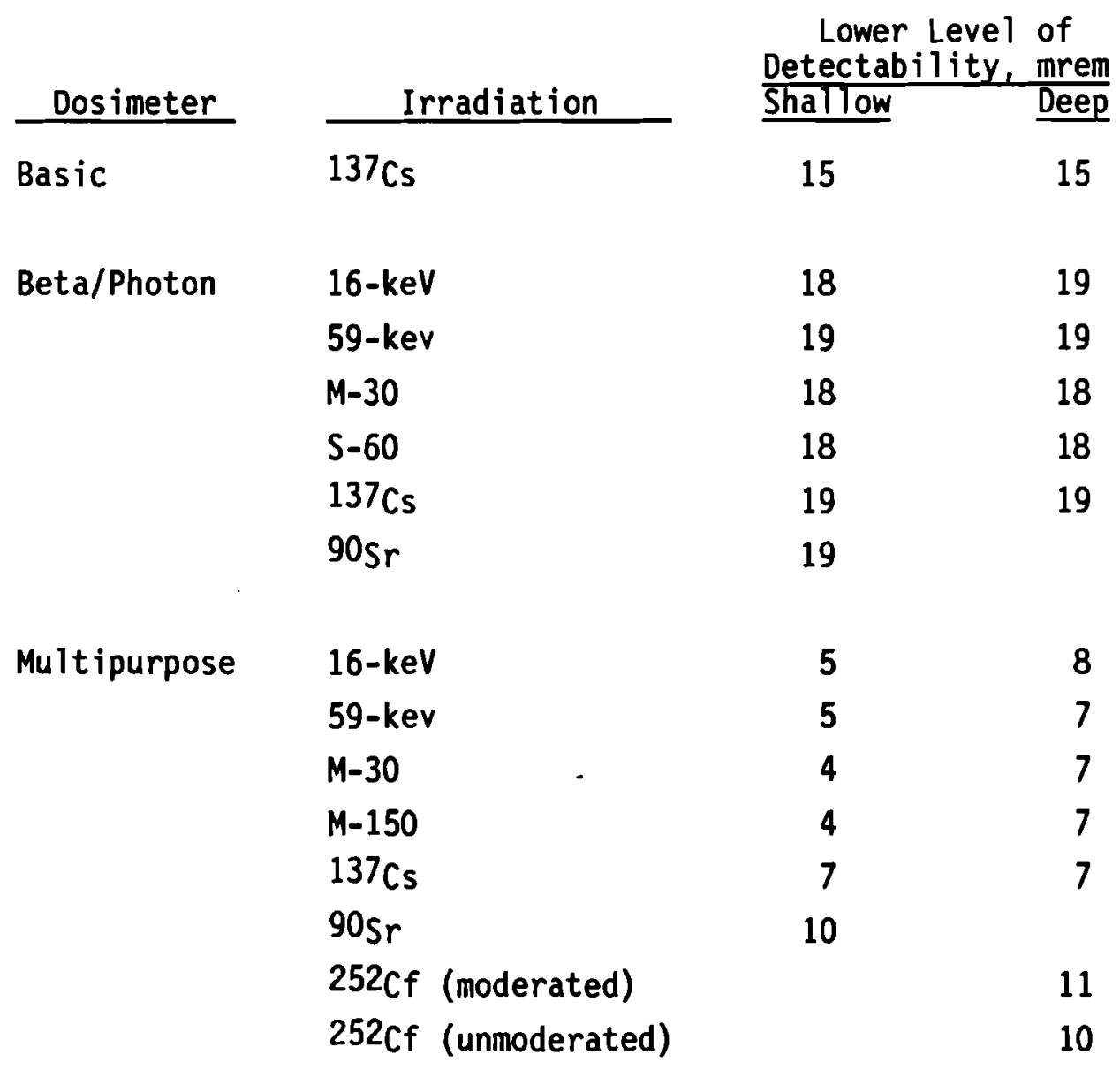

determine individual chip sensitivity factors (CSFs) for each basic dosimeter, an average CSF of 1.7 was used. This factor was used for the vast majority of basic dosimeters worn by personnel during 1987. Since year-end exchange, all of these dosimeters have received individually determined CSFs involving two successive exposures to $1 \mathrm{R}$ of $137 \mathrm{Cs}$ gamma radiation and processing. The 1987 year-end basic dosimeter results were reevaluated using these factors. The use of the individually determined factors eliminated the positive bias previously observed. This is evident in Figure 4, which shows the distributions of the basic dosimeters prior to and following dose calculation using the individually determined CSFs. The individual doses originally recorded for 1987 were not changed to reflect the recalculated 


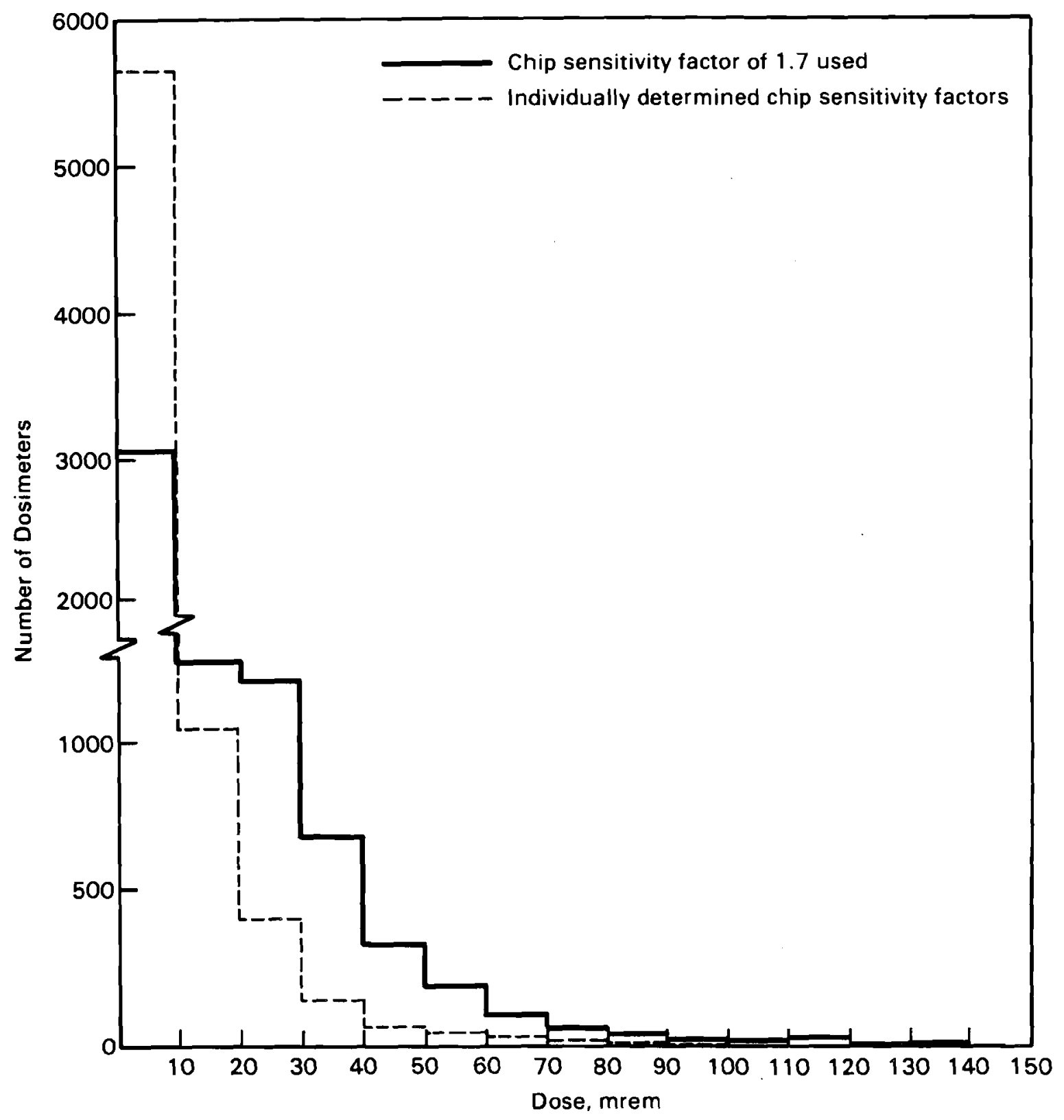

FIGURE 4. Distribution of Year-End Basic Dosimeter Results

doses because of the small effect of the CSF for most dosimeters, the time necessary to determine the CSF for the thousands of basic dosimeters, and the need to report year-end 1987 doses. 
PUBLICATIONS

Formal documentation of the Hanford External Dosimetry Program is contained in two PNL manuals, PNL-MA-583(a) and PNL-MA-568(b). In addition to these documents, several internal technical documents are used by program staff to document the design, algorithm, calibration, and dose response characteristics of the different dosimeters as well as procedures for evaluating the nuclear accident and environmental dosimeters. Letter reports are prepared and submitted to the Hanford Personnel Dosimetry Advisory Committee for review and comment for significant program issues. Copies of these letters are included in the minutes of the committee meetings and submitted to the Hanford Radiation Protection Historical Files maintained by the PNL Radiological Records Program. Reports on the following topics were submitted during 1987:

- assessment of new Hanford multipurpose dosimeter dose algorithms(c)

- assessment of basic dosimeter objective, distribution of results during 1986, adequacy of quality control, and feasibility of flagging recorded doses less than $100 \mathrm{mrem}(\mathrm{d})(\mathrm{e})$

- committee direction to assess CSFs for basic dosimeters and submittal of dosimeters for DOELAP accreditation(d)

(a) Pacific Northwest Laboratory (PNL). 1987. Location of Criticality Alarms and Nuclear Accident Dosimeters at Hanford. PNL-MA-583, Pacific Northwest Laboratory, Richland, Washington.

(b) Pacific Northwest Laboratory (PNL). 1988. Hanford External Dosimetry Program. PNL-MA-568, Pacific Northwest Laboratory, Richland, Washington.

(c) Fix, J. J. 1987. "Assessment of Dose Impact Between New and 01d Hanford Algorithms." Letter to Distribution, dated February 24, 1987, Hanford Radiation Protection Historical Files, Pacific Northwest Laboratory, Richland, Washington.

(d) Fix, J. J. 1987. "Information Regarding Accreditation of Basic Dosimeter." Letter to Distribution, dated March 25, 1987, Hanford Radiation Protection Historical Files, Pacific Northwest Laboratory, Richland, Washington.

(e) Jech, J. J. 1987. "Basic Dosimeter Review by Hanford Dosimetry Advisory Committee." Letter to Distribution, dated March 25, 1987. Hanford Radiation Protection Historical Files, Pacific Northwest Laboratory, Richland, Washington. 
- assessment of Hanford practice of rounding dosimeter results to multiples of 10 mrem(a)

- Hanford practice for supplemental dosimeters(b)(c)

- adoption of Hanford Practice for assessing skin dose from contamination. (d) (e)

\section{EXTERNAL PROFESSIONAL ACTIVITIES}

Outside professional activities of the program staff during CY 1987 are listed here.

- Fix, J. J.--Chairman of the Health Physics Society Standards Committee (HPSSC) Working Group to develop a standard titled "How to Estimate the Overall Accuracy in Occupational Dose Determinations."

- Fix, J. J.--Chaiman of the DOELAP Oversight Board as identified in DOE 5480.15 (DOE 1987).

- Fix, J. J.--Member of the HPSSC Working Group to revise American National Standards Institute (ANSI) Standard N319-1976, "American National Standard for Personnel Neutron Dosimeters (Neutron Energies Less Than $20 \mathrm{MeV}$ )" (ANSI 1976).

(a) Fix, J. J. 1987. "Hanford Personnel Dosimetry Advisory Committee Meeting of April 8, 1987." Letter to Distribution, dated April 10, 1987. Hanford Radiation Protection Historical Files, Pacific Northwest Laboratory, Richland, Washington.

(b) Fix, J. J. 1988. "Minutes of Hanford Personnel Advisory Committee Meeting on January 14, 1988." Letter to Distribution, dated January 22, 1988, Hanford Radiation Protection Historical Files, Pacific Northwest Laboratory, Richland, Washington.

(c) Lyon, M. 1987. "Hanford Personnel Dosimetry Advisory Committee Meeting on November 5, 1987." Letter to Distribution, dated November 25, 1987, Hanford Radiation Protection Historical Files, Pacific Northwest Laboratory, Richland, Washington.

(d) Fix, J. J., and L. A. Rathbun. 1987. "Proposed Hanford Practice to Assess Skin Dose From Contamination." Letter to Distribution, dated April 1, 1987, Hanford Radiation Protection Historical Files, Pacific Northwest Laboratory, Richland, Washington.

(e) Rathbun, L. A. 1987. "Draft Procedure for Skin Dose Assessment." Letter to Distribution, dated October 28, 1987. Hanford Radiation Protection Historical Files, Pacific Northwest Laboratory, Richland, Washington. 
- Nichols, L. L.--Chairman of the Health Physics Society Standards Committee.

- Rathbun, L. A.--Member of the American Society of Testing and Materials Task Group E-10-04-16 to write a standard titled "How to Perform Field Measurements of Beta Spectra." 


\section{HANFORD INTERNAL DOSIMETRY PROGRAM}

The Hanford Internal Dosimetry Program was initiated in late 1944 to provide for the assessment and documentation of occupational doses to employees from intakes of radionuclides at Hanford. The program, administered in support of Hanford radiation protection programs as required by DOE 5480.1 (DOE 1981a) and the Hanford Site Services Handbook (RL 1983), and it provides the following services:

- administration of the routine bioassay monitoring program for internally deposited radionuclides

- investigation of potential internal exposures and assessment and documentation of resulting dose equivalents

- monitoring and assessment of bioassay laboratory performance

- selection and application of appropriate models, procedures, and practices for evaluating internal radionuclide deposition and resulting dose

- technical guidance and support to Hanford contractors with regard to internal dosimetry matters.

These program services and other activities are discussed in the following subsections.

\section{ROUTINE PROGRAM}

The Hanford Internal Dosimetry Program provides for routine bioassay monitoring of workers potentially internally exposed to radionuclides at Hanford. Bioassay monitoring includes in vivo measurements and excreta analysis. If an intake of radionuclides potentially resulting in a dose equivalent at or above the investigation level is identified, either through the routine monitoring program or by workplace monitoring (e.g., air sampling, contamination surveys) an investigation and assessment of internal dose is performed. The investigation level is $1 \%$ of the maximum permissible body burden (MPBB) in Publication 2 of the International Commission for Radiological Protection (ICRP 1959) for systemic uptakes of long-lived 
bone-seeking radionuclides and $1 \%$ of the DOE radiation protection standard (RPS) in DOE 5480.1 (1981a) for all other internal exposures.

Routine bioassay monitoring frequencies are developed based on the concept of potentially missed dose as discussed in the Hanford Dosimetry Evaluation Manual (PNL-MA-575). (a) Except for work in the Uranium Oxide Plant (200 W Area), the 306-W Specialty Machine Shop (300 Area), the Fuels Production Facility (300 Area) where uranium with enrichments less than 1.25\% $235 \mathrm{U}$ are handled, and some laboratory and shop work involving tritium, any internal exposures to radionuclides are assumed to occur only as a result of accidental circumstances. In the uranium facilities, internal exposures are controlled through engineered and administrative measures; however, because complete containment of the uranium and tritium is not always provided, the existence of low-level chronic exposures in these cases is assumed in the design and operation of the bioassay monitoring program.

Tables 3 and 4 summarize minimum detectable activities (MDAs) for routine bioassay measurements and follow-up levels for initiating an investigation and assessment of internal dose. The results of all bioassay measurements are recorded in the ORE database.

Assessments of dose equivalent are based primarily on bioassay measurement data considering the specific physical and radiological characteristics of the involved contaminants. Biokinetic models used to interpret bioassay measurement data and to assess radionuclide distribution and retention are listed in Table 5. Factors for converting cumulated internal radioactivity to dose are based on specific effective energy (SEE) factors listed in ICRP 30 (1979) modified by using a quality factor for alpha particles of $Q=10$.

Computer codes used for evaluating bioassay measurement data are LUNGDOS Version 2.0 and PUCALC(PCPLOT) Version 2.0 and GENMOD (Johnson and Carver 1981).

(a) Pacific Northwest Laboratory (PNL). 1982. Hanford Dosimetry Evaluation Manual. PNL-MA-575, Pacific Northwest Laboratory, Richland, Washington. 
TABLE 3. Minimum Detectable Activities and Follow-Up Levels for Routine Urinalyses During 1987

\begin{tabular}{|c|c|c|}
\hline Radionuclide & $\operatorname{MDA}(\mathrm{a})$ & $\begin{array}{c}\text { Foll low-up Leve } 1 \\
\text { (Sampling frequency) (b) }\end{array}$ \\
\hline $90 S r$ & $2 \mathrm{dpm} / \mathrm{s}$ & $10 \mathrm{dpm} / \mathrm{s}(\mathrm{A})$ \\
\hline $238 \mathrm{pu}$ & $0.02 \mathrm{dpm} / \mathrm{s}$ & $>M D A(A)$ \\
\hline $239 \mathrm{pu}$ & $0.02 \mathrm{dpm} / \mathrm{s}$ & $>M D A(A)$ \\
\hline $241_{A m}$ & $0.02 \mathrm{dpm} / \mathrm{s}$ & $>M D A(A)$ \\
\hline $244 \mathrm{Cm}$ & $0.02 \mathrm{dpm} / \mathrm{s}$ & $>M D A(A)$ \\
\hline U-natural & $0.5 \mu \mathrm{g} / 1$ & $5 \mu \mathrm{g} / \mathrm{s}(\mathrm{BW})$ \\
\hline U-natural & $0.14 \mu \mathrm{g} / \mathrm{l}(\mathrm{c})$ & $0.2 \mu \mathrm{g} / \mathrm{s}(Q, A)(\mathrm{d})$ \\
\hline
\end{tabular}

(a) Specified MDA based on Type I and Type II errors of $5 \%$ as described in the 1987 Statement of Work for the Fifth Operational Year of Analytical Services of Subcontract B-2472-A-I except for the noted U-natural measurement, which is given as the actual achieved MDA for fiscal year (FY) 1987.

(b) Investigation of a potential internal exposure is performed whenever these values are exceeded. Routine bioassay monitoring frequency: A-annual, Q-quarterly, M-monthly, BW-biweekly.

(c) Actual achieved MDA for FY 1987 based on evaluation of quality control data.

(d) Upper level of expected environmentally derived uranium in urine for the Hanford region. 
TABLE 4. Minimum Detectable Activities and Follow-Up Levels for In Vivo Measurements During 1987

Measurement-Radionuclide(a) $\quad$ MDA, $\mathrm{nCi}(\mathrm{b}) \quad \underline{\text { Follow-up Level(c) }}$

Whole Body Count

$\begin{array}{rcc}22 \mathrm{Na} & 1.5 & \text { Det. Activity } \\ 54 \mathrm{Mn} & 3 & 6 \mathrm{nCi} \\ 59 \mathrm{Fe} & 6 & \text { Det. Activity } \\ 60 \mathrm{Co} & 3 & 5 \mathrm{nCi} \\ 106 \mathrm{Ru} & 12 & \text { Det. Activity } \\ 154 \mathrm{Eu} & 4.5 & \text { Det. Activity } \\ 137 \mathrm{Cs} & 3 & 6 \mathrm{nCi} \\ 95 \mathrm{Zr} & 3 & \text { Det. Activity }\end{array}$

Lung Count

$144 \mathrm{Ce}$

0.6

$3 \mathrm{nCi}$

$154 \mathrm{Eu}$

0.07

$1.6 \mathrm{nCi}$

232Th

0.57

Det. Activity

235u

0.12

Det. Activity

$238 \mathrm{U}(234 \mathrm{Th})$

1.8

Det. Activity

$238 \mathrm{Pu}$

30

Det. Activity

$239 \mathrm{Pu}$

75

Det. Activity

241Am

0.18

Det. Activity

(a) For selected radionuclides. Detection of radionuclides not listed results in follow-up investigation.

(b) From PNL-MA-574 (Pacific Northwest Laboratory [PNL]. 1986. Whole Body Counting Manual. PNL-MA-574, Pacific Northwest Laboratory, Richland, Washington).

(c) Investigation of a potential internal exposure is performed whenever the follow-up level is exceeded. Calculated levels are based on assumption of intake at the investigation level assuming a mixture of fission and activation products. Others are based on desire to investigate any positive measurement. 
IABLE 5. Models Used to Interpret Bioassay Data During 1987

\begin{tabular}{|c|c|}
\hline System & Model \\
\hline Respiratory Tract & TGLD Mode1 (ICRP 30) \\
\hline GI Tract & ICRP GI Tract Model (ICRP 30) \\
\hline Pu Urine Excretion & Jones' Function (Jones 1985) \\
\hline Sr Urine Excretion & Dolphin-Eve Function (Dolphin and Eve 1963) \\
\hline
\end{tabular}

All Internal Dose Evaluation Reports are identified by a unique evaluation number. Prior to 1987 the evaluation number was assigned sequentially. Beginning in 1987 the assigned evaluation number consists of a two-digit number for the year when the intake was identified followed by a three-digit incident number, a two-digit individual number, and a revision letter. For example, the first individual identified for an internal dose assessment using the new evaluation number scheme was assigned 87001-01A. If the evaluation were the result of an internal exposure incident involving several persons, each evaluation would be identified using the same first five numbers, but each would be assigned a different individual identification number. For example, the evaluation performed for the second individual would be assigned an evaluation number of 87001-02A. The final character in the evaluation number identifies if the evaluation is the initial assessment "A", or is a revision to a previous assessment "B,C,D, .--".

\section{MONITORING AND ASSESSMENT ACTIVITIES}

During 1987, 13,538 bioassay measurements were performed in support of Hanford activities. This includes the performance of 13,144 routine measurements, an increase of $27 \%$ over the number performed in 1986.

Tables 6 and 7 summarize the types and numbers of the routine urinalyses and in vivo bioassays, respectively. Of these routine measurements, followup investigations were initiated for $21(<0.2 \%)$ because of indications of potential internal exposure above the investigation level. 
TABLE 6. Routine Urinalyses Performed During 1987(a)

\begin{tabular}{|c|c|c|c|c|c|}
\hline Nucl ide & DOE & KEH & PNL & WHC & Total \\
\hline $238,239 \mathrm{Pu}$ & 0 & 0 & 188 & 1531 & 1719 \\
\hline $90 s r$ & 0 & 0 & 10 & 1023 & 1033 \\
\hline $241_{\mathrm{Am}}$ & 0 & 0 & 54 & 9 & 63 \\
\hline $244 \mathrm{Cm}$ & 0 & 0 & 34 & 0 & 34 \\
\hline $3 H$ & 0 & 0 & 40 & 0 & 40 \\
\hline U-natural & 0 & 0 & 191 & 644 & 835 \\
\hline Total & 0 & 0 & 517 & 3207 & 3724 \\
\hline
\end{tabular}

(a) According to contractor organizations in effect at year-end (WHC includes BCSR employees).

TABLE 7. Routine In Vivo Measurements Performed During 1987 (a)

\begin{tabular}{|c|c|c|c|c|c|}
\hline Type & DOE & KEH & PNL & WHC & Total \\
\hline WBC & 19 & 715 & 1018 & 6125 & 7877 \\
\hline Chest & 0 & 0 & 263 & 1279 & 1542 \\
\hline Thyroid & 0 & 0 & 1 & 0 & 1 \\
\hline Total & 19 & 715 & 1282 & 7404 & 9420 \\
\hline
\end{tabular}

(a) According to contractor organizations in effect at year-end (WHC includes BCSR employees).

As a supplement to the routine measurements, 113 bioassay measurements were performed to support efforts of the concept of "as low as reasonably achievable" (ALARA), to verify the adequacy of radiation protection measures, and to assure workers and management that radiation controls were functioning as intended.

Investigations of possible internal exposure to radionuclides were performed whenever there was an indication of an exposure that could result in an internal dose exceeding the investigation level of $1 \%$ of a DOE RPS or $1 \%$ of a MPBB. Doses potentially exceeding the investigation level are identified by: 
- workplace surveillance (e.g., air sampling, contamination survey, contaminated wound)

- specially requested bioassay measurements based on consideration of exposure potential

- routine bioassay measurements.

During 1987 there were 14 reported potential internal exposure incidents involving 20 workers identified through workplace surveillance--compared to 44 incidents involving 63 workers in 1986. Of the 20 persons, 13 were potentially exposed to short-lived fission and/or activation products, 4 to uranium, 2 to plutonium, and 1 to $90 \mathrm{Sr}$. Seventeen of the exposures were via inhalation and three were from minor wounds. These are summarized by contractor in Table 8. None of the individuals involved were determined to have incurred internal doses in excess of $1 \%$ of a DOE RPS.

TABLE 8. Summary of Potential Internal Exposure Incidents During 1987(a)

\begin{tabular}{|c|c|c|c|c|c|}
\hline & Number & of Inc & nts ( & vidual & $\frac{\text { olved) }}{\text { Total }}$ \\
\hline Area & $\overline{D O E}$ & KEH & $\underline{\mathrm{PNL}}$ & WHC & Total \\
\hline $100 \mathrm{~N}$ & 0 & $4(8)$ & 0 & $2(2)$ & $6(10)$ \\
\hline $200 \mathrm{E}$ & 0 & 0 & 0 & $2(2)$ & $2(2)$ \\
\hline $200 \mathrm{~W}$ & 0 & 0 & 0 & 0 & 0 \\
\hline 300 & 0 & $1(2)$ & $4(5)$ & $1(1)$ & $6(8)$ \\
\hline 400 & 0 & $\underline{0}$ & 0 & $\underline{0}$ & $\underline{0}$ \\
\hline Total & 0 & $5(10)$ & $4(5)$ & $5(5)$ & $14(20)$ \\
\hline
\end{tabular}

(a) According to contractor organizations in effect at year-end.

Retrospective bioassay measurements to confirm an internal exposure and assess the resulting internal dose are performed upon any indication that an internal exposure potentially exceeds the investigation level. During 1987, 281 retrospective bioassay measurements were performed.

Internal dose assessments are performed and documented whenever an investigation of potential internal exposure is performed. Assessments are also performed to update or revise previously issued assessments. During 
1987, 135 internal dose assessments addressing radionuclide intakes occurring in or prior to 1987 were documented as follows:

- seventy-five evaluation reports were issued for potential internal exposure incidents, and two concluded that doses in excess of the investigation level had occurred

- thirty-one evaluation reports were issued as a result of specially requested bioassay measurements, and one of these resulted in an internal dose exceeding $1 \%$ of the RPS. This case was later reevaluated at less than $1 \%$ of the RPS based on receipt of additional information concerning exposure.

- fifty-one evaluation reports were issued as a result of a routine bioassay measurement, and eight resulted in doses exceeding $1 \%$ of the RPS. In two cases, the exposures had occurred prior to employment at Hanford.

- sixteen evaluation reports were re-evaluations of previously assessed internal doses, based on additional data obtained since the initial evaluation.

Table 9 summarizes the internal dose status of the Hanford workforce as of the end of 1987.

TABLE 9. Internal Dose Status of Hanford Workforce at 1987 Year-End

Percent of RPS or MPBB

$>1-5 \%$

$>5-50 \%$

$>50-100 \%$

$>100 \%$

Total

\begin{tabular}{|c|c|c|c|c|}
\hline \multicolumn{5}{|c|}{ Number of Workers } \\
\hline DOE & $\overline{\mathrm{KEH}}$ & PNL & WHC & Total \\
\hline 1 & 3 & 14 & 34 & 52 \\
\hline 0 & 2 & 13 & 28 & 43 \\
\hline 0 & 0 & 0 & 1 & 1 \\
\hline 1 & 0 & 0 & 1 & 2 \\
\hline 2 & 5 & 27 & 64 & 98 \\
\hline
\end{tabular}




\section{BIOASSAY ANALYTICAL SERVICES}

During 1987 the bioassay analytical services laboratory's statement of work was modified to reflect new criteria; routine monitoring and documentation of the laboratory's performance continued; and an investigation into the importance of $147 \mathrm{Pm}$ to the internal dosimetry of mixed fission products was completed.

Changes to the Statement of Work

Several changes in methods for specifying analytical laboratory performance were implemented by the bioassay (in vitro) laboratory. The Statement of Work(a) for United States Testing Company, Inc. (UST) was modified effective October 1, 1987 to be consistent with criteria and methods in draft ANSI N13.30, Bioassay Performance Standards. (b) Specification of minimum detectable amounts, bias, and precision were modified. The changes were based on a review of the draft standard by Internal Dosimetry, a PNL statistician, and UST. The resulting changes are considered to be compatible with the draft ANSI standard, but are not in all cases identical to the formulas and criteria in the standard.

Similar changes for calculating the MDA as specified in draft ANSI N13.30 had been previously implemented by the Whole Body Counting Facility and are documented in the Whole Body Counting Manual. (c)

Quality Control--United States Testing Company, Inc.

The internal quality control (QC) program operated by UST provides for monitoring and documenting laboratory performance. The results of internal

(a) Statement of Work for Fifth Operational Year of Subcontract B-B2472-A-I (1987). Maintained in the Hanford Radiation Protection Historical Files.

(b) American National Standards Institute (ANSI). 1987. Bioassay Performance Standards. Draft ANSI N13.30, American National Standards Institute, New York, New York.

(c) Pacific Northwest Laboratory (PNL). 1986. Whole Body Counting Manual. PNL-MA-574, Pacific Northwest Laboratory, Richland, Washington. 
QC samples are issued in an annual letter report.(a) The report covering QC samples analyzed in fiscal year (FY) 1987 showed performance to be satisfactory with respect to contractual requirements except for the following:

- americium-241 - About $16 \%$ of the spikes for normal and priority processing had low bias such that the allowed uncertainty was out of compliance. United States Testing Company, Inc., began an investigation to determine cause and make improvements.

- uranium - Twelve percent of the spikes had poor precision such that the allowed uncertainty was out of compliance. Problems with the fluorimeter were discovered and fixed.

- strontium-90 - During 1987 the mean blank value of QC test samples exceeded the laboratory's internal control of $1.0 \mathrm{dpm} / \mathrm{sample}$ and the processing of $90 \mathrm{Sr}$ was temporarily suspended. The cause of the increased blank sample values was determined to be the introduction of trace levels of contamination during the analytical process. The exact nature and source of the contamination has not been determined despite extensive efforts to clean the laboratory and identify the source. Analys is of the laboratory's performance indicated that despite the increase in the mean blank value, the contractual performance specification was still being met. Processing for $90 \mathrm{Sr}$ was recommenced, without apparent resolution of the problem, and mean blank levels have remained elevated but stable.

\section{Quality Control--External Audit Sample Program}

The Hanford Internal Dosimetry Program submits samples containing known quantities of radionuclides in urine to UST. The samples are submitted blind; that is, they are made to appear to be normal routine urine samples. This external audit sample program provides a check on the laboratory's own

(a) Robinson, A. V. 1987. Annual Bioassay Quality Control Report for 1987 Fiscal Year. Letter report to Don Bihl, dated November 9, 1987, Hanford Radiation Protection Historical Files, United States Testing Company, Inc., Richland, Washington. 
internal QC program. Urinalyses for 90Sr, 238Pu, 239Pu, 241 Pu, 241 $\mathrm{Am}$, and uranium via two different methods were tested during 1987 and are documented in an annual report.(a) For the test period 1987, all of the analyses except for 241Pu met or exceeded specifications in the Statement of Work.

Plutonium-241 was tested for the first time in 1987. The calculated detection level did not meet the 2 -dpm/sample requirement because of a high mean blank value and poor precision on blanks and low-level spikes. However, performance was acceptable on samples spiked at about 10 times the contractual detection level.

Sequential $90 \mathrm{Sr}, 144 \mathrm{Ce}, 147 \mathrm{Pm}$ Urinalysis

In 1986 it was found that the $90 \mathrm{Sr}, 144 \mathrm{Ce}, 147 \mathrm{Pm}$ urinalys is was not in compliance with requirements in the Statement of Work. Rather than expending time and money to improve the procedure, Internal Dosimetry first investigated the importance of $147 \mathrm{pm}$ to the internal dosimetry of mixed fission products under likely intake scenarios. The investigation revealed that $147 \mathrm{Pm}$ is not an important contributor to internal dose relative to other fission products that would be expected to be involved in an intake. It was concluded that the sequential $90 \mathrm{Sr}, 144 \mathrm{Ce}, 147 \mathrm{Pm}$ procedure should not be requested for urine samples unless it was known that the amounts of $90 \mathrm{Sr}$ and $144 \mathrm{Ce}$ in the samples were of the same order of magnitude as or less than the $147 \mathrm{Pm}$. Because this situation was determined to be unlikely, no additional research and development of the procedure has been recommended at this time.

\section{SUPPORTING INVESTIGATIONS AND STUDIES}

Supporting work conducted during 1987 included upgrades to bring the program into compliance with draft DOE 5480.11 (b) and the development of educational resources.

(a) Bih1, D. E. 1988. Results of the Bioassay Audit Program for Fiscal Year 1987. Letter report, dated February 19, 1988, Hanford Radiation Protection Historical Files, Pacific Northwest Laboratory, Richland, Washington.

(b) U.S. Department of Energy (DOE). 1987. Radiation Protection for the Occupational Worker. Draft DOE 5480.11, U.S. Department of Energy, Washington, D.C. 
Upgrades Supporting Implementation of DOE 5480.11

Revision of Chapter XI, "Requirements for Radiation Protection," in DOE 5480.1 (DOE 1981) is expected during 1988. Several tasks aimed at supporting the implementation of the requirements in the revised Order were conducted during the year and will be completed during 1988. Most of these will be covered in next year's annual report. Among these tasks was the development of an internal dose database for Hanford called INTERTRAC. The database maintains organ and effective dose equivalents for each evaluated occupational internal exposure that exceeds the recording level, and creates internal exposure reports. Examples of the types of data that could be included in reports are:

- annual organ and effective dose equivalents for each intake

- annual organ and effective dose equivalents for all intakes combined

- 50-year committed organ and effective dose equivalents for each intake

- cumulative organ and effective dose equivalents through a specified age.

INTERTRAC now contains records on 288 individuals that have had internal dose evaluations. Of these, 99 have internal doses that exceeded the recording level.

Development of an Educational Videotape

The Internal Dosimetry Program developed a videotape titled "Monitoring Internal Exposure at Hanford." The videotape is approximately 11 minutes long and covers the following material:

- differences between internal and external exposure

- routes of potential radioactivity intake

- metabolism of radionuclides

- workplace indications of an intake

- Hanford bioassay techniques

- worker's role in monitoring internal exposure. 
The videotape is suitable for stand-alone presentations such as radiation worker training classes and safety meetings, or it can be used as a starting point for discussions by radiation protection staff. Two previously developed pamphlets available from PNL Personnel Dosimetry, "The Hanford Whole Body Counting Center" and "Monitoring Internal Exposure by Analys is of Radioactivity in Urine," are used as supplements to the videotape.

\section{SPECIAL INTERNAL DOSIMETRY ASSESSMENTS}

A plutonium wound case, post-mortem bioassay measurement update, and Chernobyl-related radionuclide measurements of Hanford workers comprise the special internal dosimetry assessments for 1987.

Status of a 1985 Plutonium-Contaminated Wound Case

Ongoing monitoring of a plutonium-contaminated puncture wound that occurred in 1985 continued to indicate that the residual activity at the wound site is relatively stable at levels comparable to what has been observed since approximately 3 months following the injury. In vivo measurements of the liver continue to show no detectable deposition at 17 months following termination of DTPA chelation therapy, even when the spectral data from the repeated individual measurements are combined. Individual in vivo skeleton measurements likewise show no detectable activity. However, a lowlevel skeleton content slightly above the MDA is indicated by statistical summing of the spectrums from the individual measurements. The trend appears to be one of a gradually increasing skeleton burden for each year post intake. Urinary excretion of plutonium and americium continues to appear to be relatively constant at about 1.0 and $0.1 \mathrm{dpm} /$ day, respectively.

A single intravenous injection of Ca-DTPA was administered on September 16, 1987. The treatment occurred approximately 15 months following termination of chelation therapy. It was performed at the worker's request because of his interest in the impact of a single treatment on observed urinary excretion. Plutonium in urine excretion increased by a factor of 60 immediately following injection. Within about 1 month, urinary excretion returned to pre-injection levels. 
A summary report(a) on the case management aspects of the incident, prepared in October 1987, noted the following specific conclusions:

- Long-term chelation therapy was extremely effective in limiting systemic deposition.

- The data will be useful for assessing the usefulness of long-term chelation therapy.

- The team approach to case management was a benefit to all parties.

- Training was implemented following the wound to increase worker awareness of chelation therapy for plutonium and to simplify the informed consent process.

- A high degree of uncertainty exists in estimating 50-year committed doses within a year following intake, particularly while chelation therapy is in process.

Final Update on H.R. McCluskey Bioassay Measurements

A final update of H.R. McCluskey's bioassay measurements was provided to DOE-RL following the death of Mr. McCluskey on August 17, 1987 at the age of 75. (b) The update summarized measurements made between 1984 and 1987. At the time of his death, Mr. McCluskey was estimated to have a systemic burden of $9.5 \mu \mathrm{Ci}$ of $241 \mathrm{Am}$, resulting from a contamination incident in 1976. The systemic burden included about $9 \mu \mathrm{Ci}$ in his skeleton and $0.5 \mu \mathrm{Ci}$ in his liver.

Measurement of Chernobyl-Related Radionuclides in Hanford Workers

Routine whole body measurements of seven Hanford workers revealed the presence of $134 \mathrm{Cs}$ and $137 \mathrm{Cs}$ attributable to environmental contamination from the April 1986 Chernobyl nuclear accident. The levels of 137 Cs detected

(a) Carbaugh, E. H. 1987. Hanford Experience with A January 1985 Plutonium-Contaminated Puncture Wound. Summary report, dated October 28, .1987, Hanford Radiation Protection Historical Files, Pacific Northwest Laboratory, Richland, Washington.

(b) Sula, M. J. Status Report of Health Physics Measurements for H. R. McCluskey. Letter to G. R. Yesberger, dated August 26, 1987, Hanford Radiation Protection Historical Files, Pacific Northwest Laboratory, Richland, Washington. 
ranged from 5 to $15 \mathrm{nCi}$. Levels of $134 \mathrm{Cs}$ were about three times lower. Discussions with individuals with detectable radiocesium revealed that all had traveled in Europe since the Chernobyl accident. The $137 \mathrm{Cs}$ screening levels currently being used for food in the European Economic Community, $10 \mathrm{nCi} / \mathrm{kg}$ (American Nuclear Society 1987), could easily account for the observed activity. This phenomenon was also noted by Hull (1987).

\section{IMPROVEMENTS IN TECHNICAL CAPABILITY}

In an effort to improve internal dosimetry technical capability, a program was conducted to determine if routine fecal monitoring for nontransportable plutonium is feasible, portable wound survey instruments were procured, and a final draft of an internal exposure sources catalog was prepared. Pilot Fecal Sampling and Analysis Program

A pilot fecal sampling and analysis program was conducted from 1986 through 1987 to determine the feasibility of routine fecal monitoring for nontransportable forms of plutonium. Approximately 50 plutonium workers participated in the sampling program. These individuals were placed on a quarterly sampling schedule with samples collected at the end of the threeday-long shift change to reduce interference from ingestion of trace levels of plutonium. The data from the measurements will be used in the preparation of guidelines and action levels for interpreting the results. The data obtained were recorded in the participating individuals' ORE records.

Initial worker acceptance of the program was poor; only 58 of 84 scheduled samples were received. Some samples obviously represented only a small portion of a day's excretion. Additional training of workers and supervisors will be provided to improve program participation.

Implementation of Portable Wound Survey Instruments

Four portable wound survey instruments, for use at the Emergency Decontamination Facility (EDF), were procured. The instruments are Eberline ESP-1 survey meters with Bicron B-1E sodium iodide detectors. The new wound survey meters can provide a rapid and direct readout of low-energy photons and thus are useful as a means for rapidly monitoring for plutonium in a wound or beneath a bandage. Although less sensitive than the wound counter 
at the EDF, the portable instrument can be used at the patient's bedside to provide an initial estimate of plutonium in wounds or on the skin. Because of their portability, the instruments can easily be moved to locations other than the EDF. A report providing calibration and operating information was prepared. (a)

\section{Internal Exposure Sources Catalog}

A final draft catalog of Hanford facilities containing sources of potential internal radionuclide exposure was prepared and submitted to site contractors for review and comment. The catalog lists the facilities by contractor and area and includes information on the radionuclide sources provided by contractors. The catalog is maintained on a computerized database and will be updated and reissued annually. Copies of each issuance of the catalog are maintained in the Hanford Radiation Protection Historical Files.

\section{PRESENTATIONS}

One presentation was made during 1987:

- Bihl, D. E. 1987. "Public Internal Radioactivity Measurement Program." Presentation to the Joint Columbia/Cascade Chapters Health Physics Society Conference, March 19, 1987, Richland, Washington.

\section{EXTERNAL PROFESSIONAL ACTIVITIES}

The program staff were involved in several related external professional activities:

- Sula, M. J.--Member of the DOE Expert Group on Internal Dosimetry, which is preparing an implementation internal dosimetry manual to accompany draft DOE 5480.11.

(a) Landis, M. R. 1987. Wound Contamination Monitoring Procedure for the Eberline ESP-1 Smart Portable and the Bicron B-1E Detector. Letter report, dated January 1987, Hanford Radiation Protection Historical Files, Pacific Northwest Laboratory, Richland, Washington. 


\section{HANFORD IN VIVO MEASUREMENT PROGRAM}

The In Vivo Measurement Program has been an integral part of personnel dosimetry at Hanford since 1959 to assist in detecting the deposition of radioactive materials in Hanford employees. Program requirements are outlined in the Hanford Site Services Handbook (RL 1983). The In Vivo Measurement Program provides for the management, operation, and maintenance of the in vivo counting facilities and equipment located in the 747-A Building, the 747-A Trailer, a mobile in vivo counting facility, and the EDF. Operating hours are from 8:00 a.m. to 4:40 p.m. on weekdays. The facilities and equipment are also available during off-hours on an on-call basis, if needed. Results of measurements are transmitted electronically to the ORE database for permanent record. Daily operational and functional checks are performed on all routinely used counting systems, which are also periodically fully calibrated to ensure their accuracy. The staff participate in intercomparison programs to further improve the accuracy of operations. The activities of this program, including special studies and development work carried on during 1987, are described in the following subsections.

\section{ROUTINE PROGRAM}

Several types of routine in vivo measurements are made on personnel. The type of measurement made on each person is determined by the type of radioactivity to which he potentially is exposed. Generally, if an employee does not work with transuranic radionuclides, only a whole body count to detect the higher energy of gamma rays from fission or activated corrosion products is done. If the work involves transuranic radionuclides, lung and whole body counts are done.

The number and types of measurements made on personnel are shown in Table 10. During 1987, 9773 measurements were made for DOE and the Hanford contractors. This number is $3.5 \%$ less than the number for 1986 . Figure 5 depicts the in vivo measurements made at the Whole Body Counting Facility since 1977. The whole body counting section of each bar includes all types of measurements except lung counts. The 1987 total of 8168 whole body 
TABLE 10. In Vivo Measurements Made During 1987(a)

\begin{tabular}{|c|c|c|c|c|c|c|c|}
\hline Contractor & $\begin{array}{c}\text { Whole Body } \\
\text { Counts }\end{array}$ & $\begin{array}{c}\text { Lung } \\
\text { Counts } \\
\end{array}$ & Thyroid & Wound & Head & 0ther & Total \\
\hline DOE & 20 & 2 & 0 & 0 & 0 & 0 & 22 \\
\hline WHC & 6,206 & 1,315 & 0 & 4 & 54 & 16 & 7,595 \\
\hline HEHF & 29 & 0 & 0 & 0 & 0 & 0 & 29 \\
\hline KEH & 808 & 11 & 0 & 1 & 0 & 0 & 820 \\
\hline PNL & 1,007 & 277 & $\underline{1}$ & $\underline{0}$ & $\underline{18}$ & 4 & $\underline{1,307}$ \\
\hline Total & 8,070 & 1,605 & 1 & 5 & 72 & 20 & 9,773 \\
\hline
\end{tabular}

(a) Includes routine and special counts.

and miscellaneous counts is about $3 \%$ lower than the total counted in 1986. Lung counts for 1987 totaled 1605 (4\% lower than in 1986).

During the 1987 routine whole body counting program 69, workers showed quantifiable amounts of gamma-emitting radionuclides. Twenty-nine of these results were $10 \mathrm{nCi}$ or higher, and forty were below this level but greater than $2 \mathrm{nCi}$. There were 61 Hanford employees whose lung counts showed the presence of quantifiable amounts of $239 \mathrm{Pu}$ and $241 \mathrm{Am}$; however, most of these were from previously known internal depositions. In addition, there were seven cases where employees had received medically administered radionuclides of $51 \mathrm{Cr}, 202 \mathrm{Tl}$, and $57 \mathrm{Co}$. Of the counts made in 1987, 14 were measured as a result of incidents that occurred on the Hanford Site and 28 were measured in response to field requests from the Hanford contractors. The results of these measurements are discussed in the Internal Dosimetry Program section of this report. 


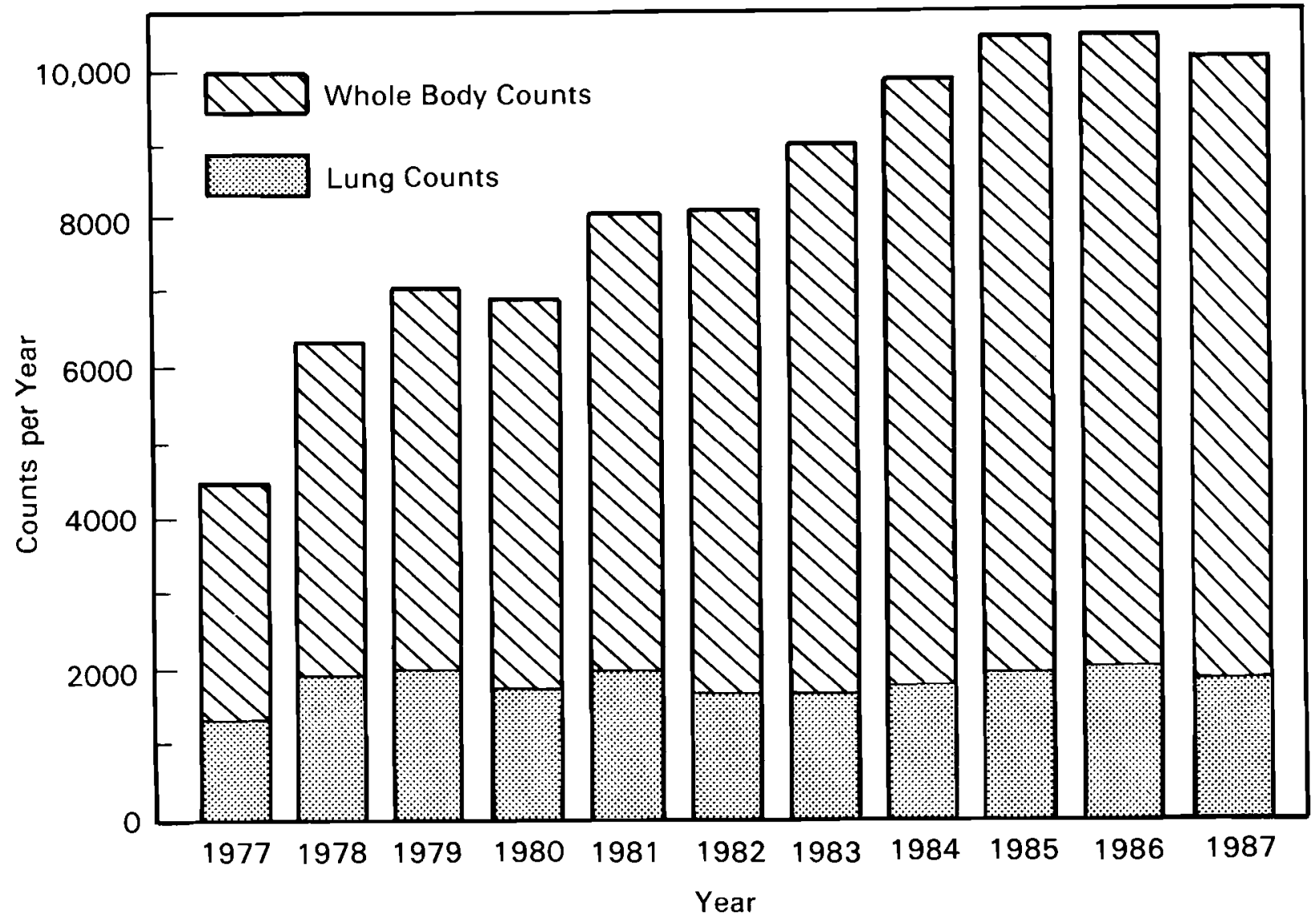

FIGURE 5. In Vivo Measurements Taken at the Hanford Whole Body Counter Facilities, 1977 Through 1987

\section{ADDITIONS OR CHANGES TO EQUIPMENT AND FACILITIES IN 1987}

Continued efforts to upgrade the accuracy, sensitivity, and operational efficiency of the whole body counter (WBC) operations resulted in removing some older equipment from service, procuring some new detectors and detector arrays, and designing new shielded rooms and work facilities.

\section{Mobile Whole Body Counter B Removed from Service}

Mobile WBC unit $B$ was removed from mobile service operations more than 10 years ago after it was no longer needed to measure $65 \mathrm{zn}$ in school children of the Tri-Cities area. Although the counter was occasionally used, there was no need for two mobile units. The decision to excess unit $B$ was based on safety considerations. Neither the truck motor nor the brakes of unit $B$ were 
powerful enough for completely safe operation on highways, so the shadow shield WBC was removed from the unit and transferred to the EDF. The truck and van were returned to the WHC Transportation Services.

Upgrade of Whole Body Counting Facilities at the Emergency Decontamination Facility

With the transfer of the shadow shield counter from mobile unit $B$ to the EDF, two WBCs are now available. One is for the standard whole body measurement of high-energy gamma rays using a large 9-3/8-in.-diameter, 4-in.-thick $\mathrm{NaI}(\mathrm{Tl})$ detector, and the other can be easily changed to accommodate a variety of detectors for measuring low-energy photons in the lungs, liver, bone, and other organs. Figure 6 shows these two counters as they were installed and upgraded during 1987. A germanium detector wound counter and its associated multichannel analyzers and a small personal computer comprise the other counting equipment located at the EDF.

\section{New Shielded Rooms}

Approval of funding for the construction of a new shielded room was received in 1987. The design was completed and a procurement specification was prepared and made ready for bid requests, but an excess steel room from the University of Utah became available for just the cost of moving it to Richland. Approval was received from DOE to place the Utah steel room 9 feet from the existing steel room and fill in the space with the steel that was procured from the Nevada Test Site a few years ago. Plans are going forward

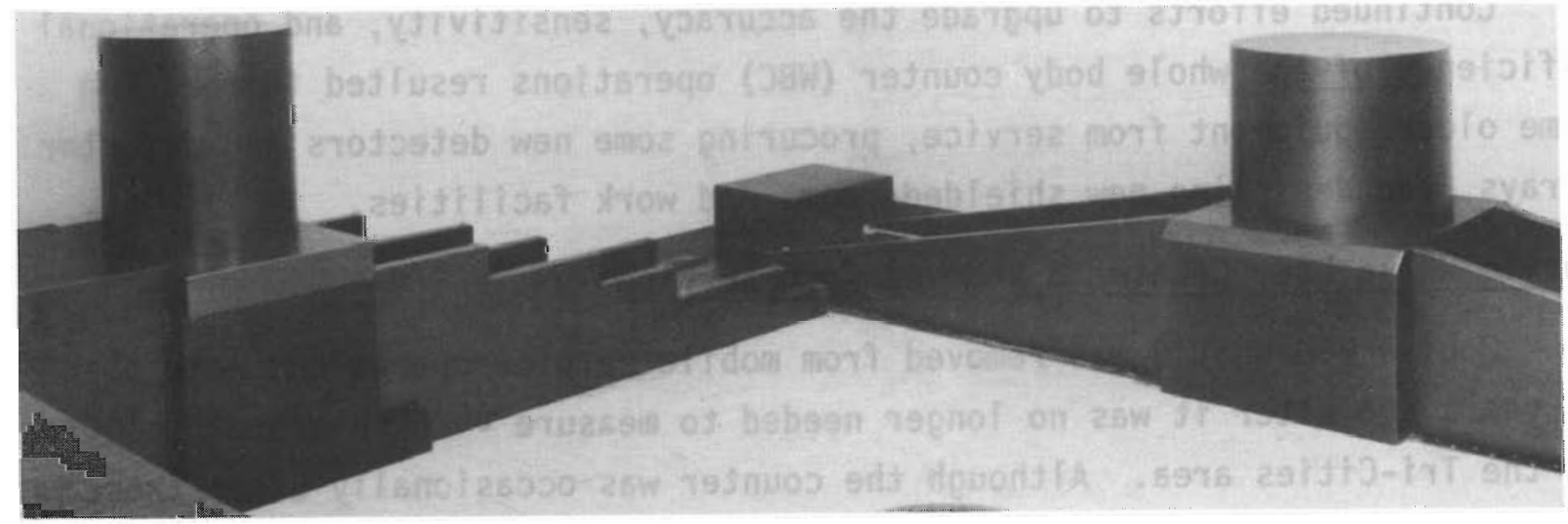

FIGURE 6. Installation and Upgrade of Two Whole Body Counters at the Emergency Decontamination Facility 
with the installation of the two rooms that should be completed in FY 1988 . The addition of these two rooms will provide many improvements in the whole body counting operations. Most important, having a second lung counter to be used in the routine counting program will allow for longer lung counts to be made and will provide for increased lung measurement sensitivity.

Design of a New Mobile Whole Body Counter

The van that houses mobile WBC unit A was constructed in 1945 and is due for replacement by the WHC Transportation Services. It will be replaced in FY 1988 with a 45 -foot van, which is 10 feet longer than the old unit. The design for the interior of the new van was completed in 1987. The new unit will include two change rooms, a storage room, and space for head and thyroid counting in addition to all the facilities that are in the old unit.

\section{New Multichannel Analyzer System}

A new Nuclear Data Model 990 microprocessor-based multichannel analyzer was purchased and put into use in 1987. The unit has specially designed circuitry requested by the WBC operations that allows it to simultaneously store and display separately the input pulses from all six detectors in the lung-counting array and also the sum spectrum of all six detectors. The multiple display capability occurs both during and at the end of lung measurements. The Model 990 has the capacity to analyze the input from several detector systems in this manner and will be used to operate two lung-counting systems when the second lung counter is put into routine use in October 1988. The unit works very well except that it occasionally shuts down for some unknown reason. The problem occurs too frequently for use with the routine program, and the source of the problem must be determined and corrected before it is put into use for the two lung-counting systems, which will begin operating in October 1988.

New Audio-Visual Communication Systems for the Shielded Rooms

High-quality, good-fidelity, audio intercom systems were installed between the operator's desk and the two shielded rooms. The intercom is voice-activated from inside the shielded rooms, and conversations are easily understood. A new closed-circuit television system with remote operation of the direction and zoom functions of the camera was installed in the steel 
room used for lung counting. The television system includes a videocassette time-lapse recorder, which allows a week of lung counter operation to be recorded on one cassette tape. This is needed so that questionable lung counts can be reviewed to determine if the detectors were in their normal position during the count or if any unusual movement or action occurred during the count to produce noise interference in the detectors.

\section{New Detector Systems}

Several new germanium detectors were procured. Five of these were planar type detectors, which completed the array of six detectors needed for the second lung counter to be placed into operation in 1988. This new array is shown in Figure 7 . In the interim, until they are installed in the second lung counter, they are being calibrated and used in special counts and studies. A large-volume, coaxial, 50\% germanium detector was received and was to be used for whole body counting of higher-energy gamma rays. A trace of 60 Co activity in the stainless steel components that support the detector was detected. The vendor agreed to let us use the detector until a new one could be manufactured, which arrived in early 1988.

\section{SPECIAL STUDIES CONDUCTED DURING 1987}

One of the objectives of the in vivo measurement program is to maintain state-of-the-art methods and instrumentation for in vivo measurements. This is accomplished through special studies directed toward obtaining improved accuracy and sensitivity for measurements. Some of the more important studies conducted during 1987 are described in this section. These studies were directed primarily at improving the calibration for radionuclides deposited in the skeleton. As more studies are done in this area, it appears that an average of estimates of skeletal content at multiple sites on the skeleton will give a more accurate estimate than measuring only one site such as the head.

\section{Documentation of Whole Body Counting Calibration Data}

The documentation and referencing of all calibration data was completed in 1987. The data were organized into 11 volumes and placed in the WBC library. The Whole Body Counting Manual was revised to include references to 


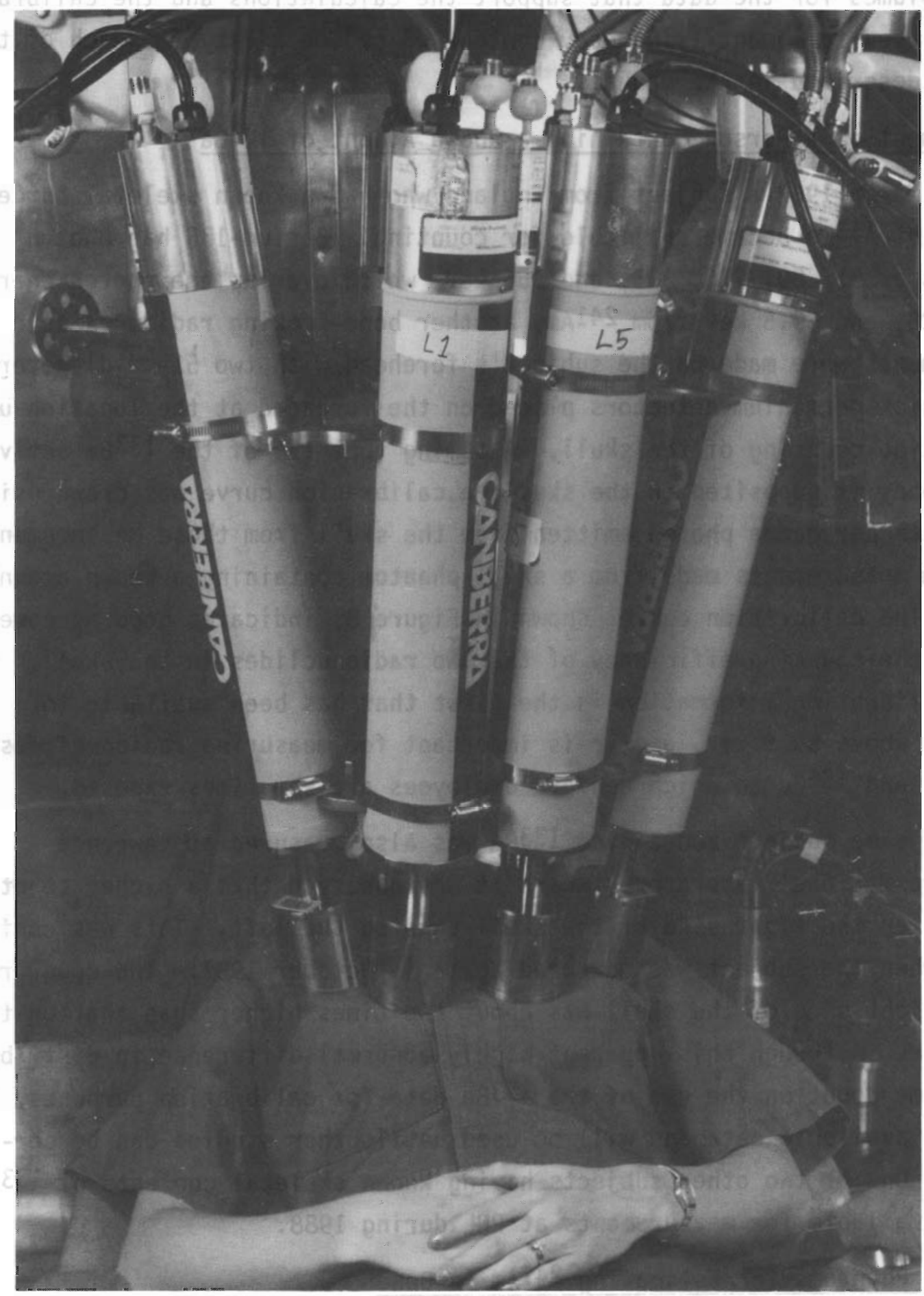

FIGURE 7. Array of Six Detectors For the Second Lung Counter 
these volumes for the data that support the calculations and the calibration factors used for quantifying body content of radioactivity for each of the methods described in the manual.

Measurement of a Person Containing a Known Amount of $133_{\mathrm{Ba}}$

In Márch 1987 a subject from England who had a known skeletal burden of $124 \mathrm{nCi}$ of $133 \mathrm{Ba}$ became available for counting. Barium-133 has photon energies of $31,80,276,303$, and $356 \mathrm{keV}$, which overlap the photon energies of 18,26 , and $59.5 \mathrm{keV}$ from $241 \mathrm{Am}$, another bone-seeking radionuclide. Measurements were made on the subject's forehead with two 51-mm-diameter by 20-mm-thick germanium detectors placed on the forehead at the location used for routine counting of the skul1. Assuming that $15 \%$ of the $133 \mathrm{Ba}$ activity in the body is deposited in the sku1l, a calibration curve was drawn using the counts per gamma photon emitted from the skull from these measurements and from measurements made from a skull phantom containing a known amount of 241 Am. The calibration curve, shown in Figure 8, indicates good agreement between the counting efficiency of the two radionuclides in the skul1. This skull calibration information is the first that has been available for energies above $59.5 \mathrm{keV}$, and it is important for measuring radionuclides such as $154 \mathrm{Eu}$ and $155 \mathrm{Eu}$ to which Hanford employees are sometimes exposed.

The same subject containing $133 \mathrm{Ba}$ was also measured at Lawrence Livermore National Laboratory, where it was observed that a higher count was obtained on the right side of the skull than on the left. This was confirmed at PNL when the subject was measured again in October 1987 . The count rate on the right side of the skull was about two times higher than that on the left side. Although this apparent highly abnormal difference in distribution casts some doubt on the use of the ${ }^{133} \mathrm{Ba}$ data for calibration purposes, it is the best available data and will be used until other studies can be performed. One or two other subjects having known skeletal contents of $133 \mathrm{Ba}$ may be available for measurements at PNL during 1988.

Skeletal Phantoms for Estimating 241Am in Bone

Human bones from a total body donation to the United States Transuranium Registry (USTR) were loaned to PNL by USTR for the construction of realistic phantoms to be used for WBC calibrations. The radioactivity in the bones 


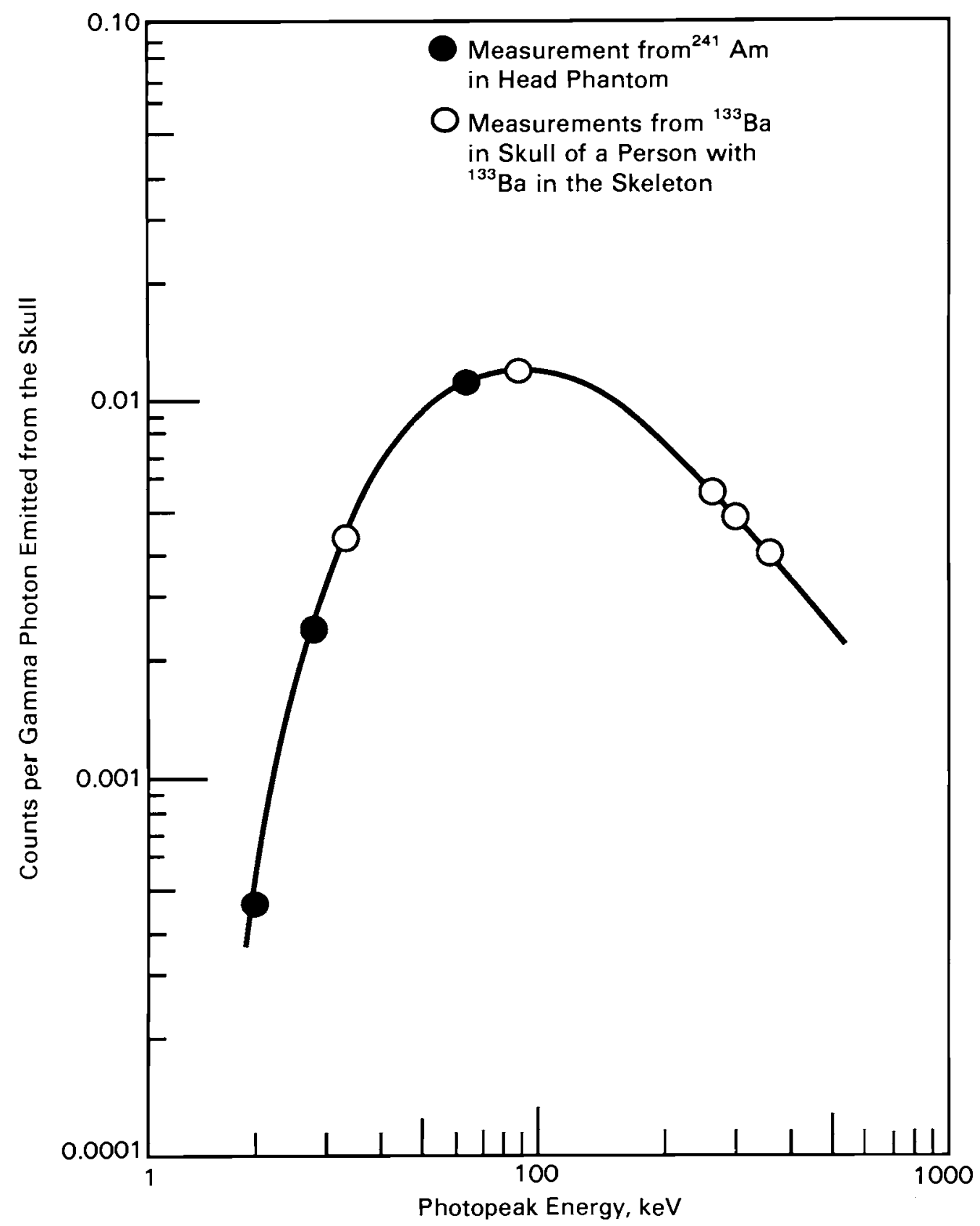

FIGURE 8. Calibration Curve for Two 51-mm-Diameter by 20-mm-Thick Detectors Located on the Forehead 
from the left side of the skeleton is well known from the detailed and accurate analysis that had been done on the bones from the right side (McInroy et a1. 1983) and from a comparative study of the count rate of the left side bones with those from the right side before the analysis was performed. A skull phantom was constructed from one half of the skull in 1985. The arm and leg phantoms were constructed in FY 1987, and the torso will be completed in FY 1988. The skull, leg, and torso phantoms were constructed at New York University Medical Center under a subcontract from PNL with DOE-HQ funding. The arm phantom was made at PNL by a graduate student and WHC employee, Gary Kephart, as a project for his master's degree.

The arm phantom is constructed of tissue-equivalent polyurethane, using every reasonable effort to reproduce the anatomically correct location of the skeleton. The posture of the arm is fixed with the elbow fully extended and the palmar surface oriented medially, as shown in Figure 9. This figure also shows the head and leg phantoms.

All of the left arm bones were used with the exception of the hamate, bones of the number four digit (metacarpal and phalanges), and small sections removed from the radius shaft, distal radius, and proximal humerus. These portions of the skeleton (which were committed to other research efforts)

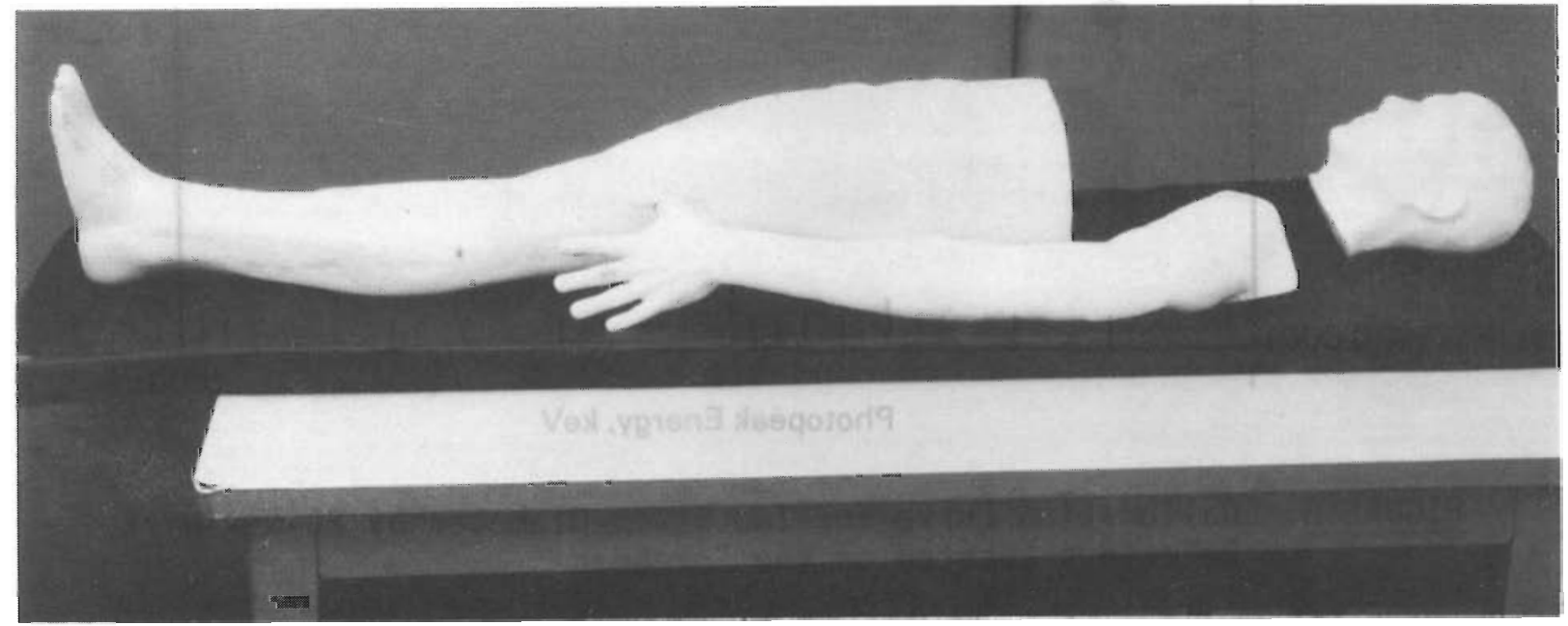

FIGURE 9. Head, Leg, and Arm Phantoms Constructed of Tissue-Equivalent Polyurethane 
were substituted with approximately spiked replacements made of boneequivalent ( $\mathrm{CaCO}_{3}$ loaded) polyurethane. The marrow spaces of the metacarpals and larger long bones were filled with adipose-equivalent polyurethane.

The arm phantom contains $8 \mathrm{nCi}$ of $241 \mathrm{Am}$, which is $6.7 \%$ of the total skeletal activity. As expected, the wrist and elbow locations give the highest count rates. When compared with the measurements on the $241_{\mathrm{Am}}$ skull phantom with two planar geranium detectors, the count rate over the wrist and elbow of the arm phantom with one detector at each location gives $33 \%$ lower counts than the skull. Even though the skull measurement provides the most sensitivity of all other locations for determining skeletal content of $241 \mathrm{Am}$, the other measurement locations on the arm and leg are very useful. Past experience in measuring several people with skeletal burdens of $241_{\mathrm{Am}}$ has shown that no single measurement site is best representative of the total skeletal burden because of small differences in distribution in different people. It is now believed that the average estimate from multiple locations will probably reduce the uncertainty in the total skeleton estimate of $241 \mathrm{Am}$ content. Other studies will be done in the future to confirm that this is true.

Reduction of External Contamination on the Skin and Clothing of Employees

Until June 1987 there were frequent occurrences of employees coming in from $N$ Reactor with low levels of contamination on their skin and clothing. A protocol was developed to study and hopefully eliminate this contamination. Starting in April 1987, when radioactivity was identified on the skin or the clothing of a person, the radiation protection personnel were notified so that they could come to the WBC to help identify, locate, and remove the contamination. The decontamination was done in places other than the WBC. After this procedure had been in place for a short time, the number of external contamination occurrences dropped dramatically to where this is no longer a problem. This reduction resulted from more attention and monitoring in the field to detect this activity before the employees leave the work area. 


\section{PUBLICATIONS}

Program staff prepared or contributed to the following publications during 1987:

- Northcutt, A. R., S. E. Binney, and H. E. Palmer. 1987. "In Vivo Counting of Americium-241 in Human Lungs and Tracheobronchial Lymph Nodes." Health Phys. 54:73-81.

- Palmer, H. E. 1987. "Upgraded In Vivo Counting for Plutonium, Americium and Uranium." In Proceedings of the Department of Energy Workshop on Radiobioassay and Internal Dosimetry, pp. 365-382, Albuquerque, New Mexico.

- Palmer, H. E., G. A. Rieksts, C. P. Brim, and M. C. Rhoads. 1987. Hanford Whole Body Counting Manual. PNL-6198, Pacific Northwest Laboratory, Richland, Washington.

- Palmer, H. E., and M. C. Rhoads. "The Measurement of Pu-239 and Am-241 in Wounds by Measuring the $L x$ rays with a $\mathrm{Si}(\mathrm{Li})$ Detector." Health Phys. (In press)

- Toohey, R. E., L. Anderson, N. Cohen, C. Berger, and E. Palmer. 1987. Current Status of Whole Body Counting to Detect and Quantify Previous Exposures to Radioactive Materials. Report to the National Cancer Institute, ORAU-285, Oak Ridge Associated Universities, Oak Ridge, Tennessee.

\section{PRESENTATIONS}

Program staff presented the following five papers during 1987:

- H. E. Palmer. 1987. "Skeletal Measurements of Low Energy Photon Emitters", "The Measurement of Plutonium-239 to Americium-241 Ratio in Wounds Using a Si(Li) Detector", and "Lung Measurements in the Sitting Versus Supine Position." Three papers presented at the Actinide In Vivo Measurements Workshop held in conjunction with the Intercalibration Committee for Measurements of Heavy Elements In Vivo, Cromwe 11, Connecticut, June 3-5, 1987. 
- H. E. Palmer. 1987. "Improved Counting Efficiencies for Measuring Plutonium-239 in the Lung in the Sitting Position." Paper presented at the 1987 Annual Health Physics Society Meeting, July 5-9, 1987, Salt Lake City.

- G. A. Rieksts. 1987. "Random Noise Peak Experience from 1500 Lung Counts Using Intrinsic Germanium Planar Detectors." Paper presented at the 33rd Annual Conference on Bioassay, Analytical, and Environmental Radiochemistry, October 6-8, 1987, Berkeley. 


\section{INSTRUMENT CALIBRATION AND EVALUATION PROGRAM}

The operation of a complete radiation protection instrument program is an integral part of Hanford radiation protection. The Instrument Calibration and Evaluation Program provides a complete radiation protection instrument service, thereby equipping the Hanford contractors with quality, reliable, and accurate instrumentation capable of performing at the level necessary to ensure personnel safety as required by draft DOE 5480.11.(a) Calibrations are performed using the guidance in ANSI N323-1978 (ANSI 1978). The Hanford Instrument Calibration and Evaluation Program consists of the following routine activities:

- procuring, testing, calibrating, and distributing instruments

- overseeing an instrument pickup and delivery service

- maintaining calibration and repair records

- surveying, decontaminating, maintaining, and calibrating instruments

- maintaining traceability of radiological and electronic calibration systems to the NBS

- servicing radiation protection emergency kits

- modifying and updating written calibration procedures as new instruments are introduced and calibration techniques are improved

- procuring, acceptance testing, calibrating, and distributing pencil dosimeters

- performing specification development and acceptance testing on all instruments purchased for pool use and as required by Hanford contractors.

These routine activities and other supporting tasks are discussed in the following subsections.

(a) U.S. Department of Energy (DOE). 1987. Radiation Protection for Occupational Workers. Draft DOE 5480.11, U.S. Department of Energy, Washington, D.C. 
ROUTINE PROGRAM

The routine program is divided into five base tasks: 1) Routine Portable Instrument Pool, 2) Hanford Instrument Evaluation Program, 3) Deployment of High-Range CPs, 4) Instrument Manual Update, and 5) Documentation of the History of Hanford Instruments. The following subsections discuss activities performed under these five tasks.

\section{Routine Portable Instrument Pool}

Table 11 summarizes the usage of portable instruments on the Hanford Site during 1987. Listed are the number and types of instrument and the percent of the total number of instruments for each contractor (i.e., KEH, UNC, RHO, WHC, and PNL). The instrument types are described in detail in PNL-MA-562. (a)

During 1987 a number of new instruments were procured to replace instruments damaged or removed from service as a result of contamination. A total of 25 ion chamber instruments were procured; these included 10 Eberline Model RO-3Bs, 5 Bicron Mode1 RSO-5s, 5 Eberline Model R0-2s, and 5 Victoreen Model 450s. Comments from the contractors evaluating the latter three instrument models will be considered for future instrument needs and orders. Seventy-five Bicron count rate meters were also received. Fifty Pancake Probes were fabricated by PNL Craft Services personnel and are now in the instrument pool.

\section{Hanford Instrument Evaluation Program}

Each year many new instruments become available from the manufacturers. The Hanford Instrument Evaluation Program has been established to evaluate for use at Hanford instruments designated by the Hanford Instrument Evaluation Committee, which includes representatives from each Hanford contractor.

Ion chamber dose rate instruments, competitors to the CP and discussed in the preceding section, were received in 1987 . Their performance against

(a) Pacific Northwest Laboratory (PNL). 1982. Radiation Protection Instrument Manual. PNL-MA-562, Pacific Northwest Laboratory, Richland, Washington. 
TABLE 11. Portable Instrument Usage for Calendar Year 1987

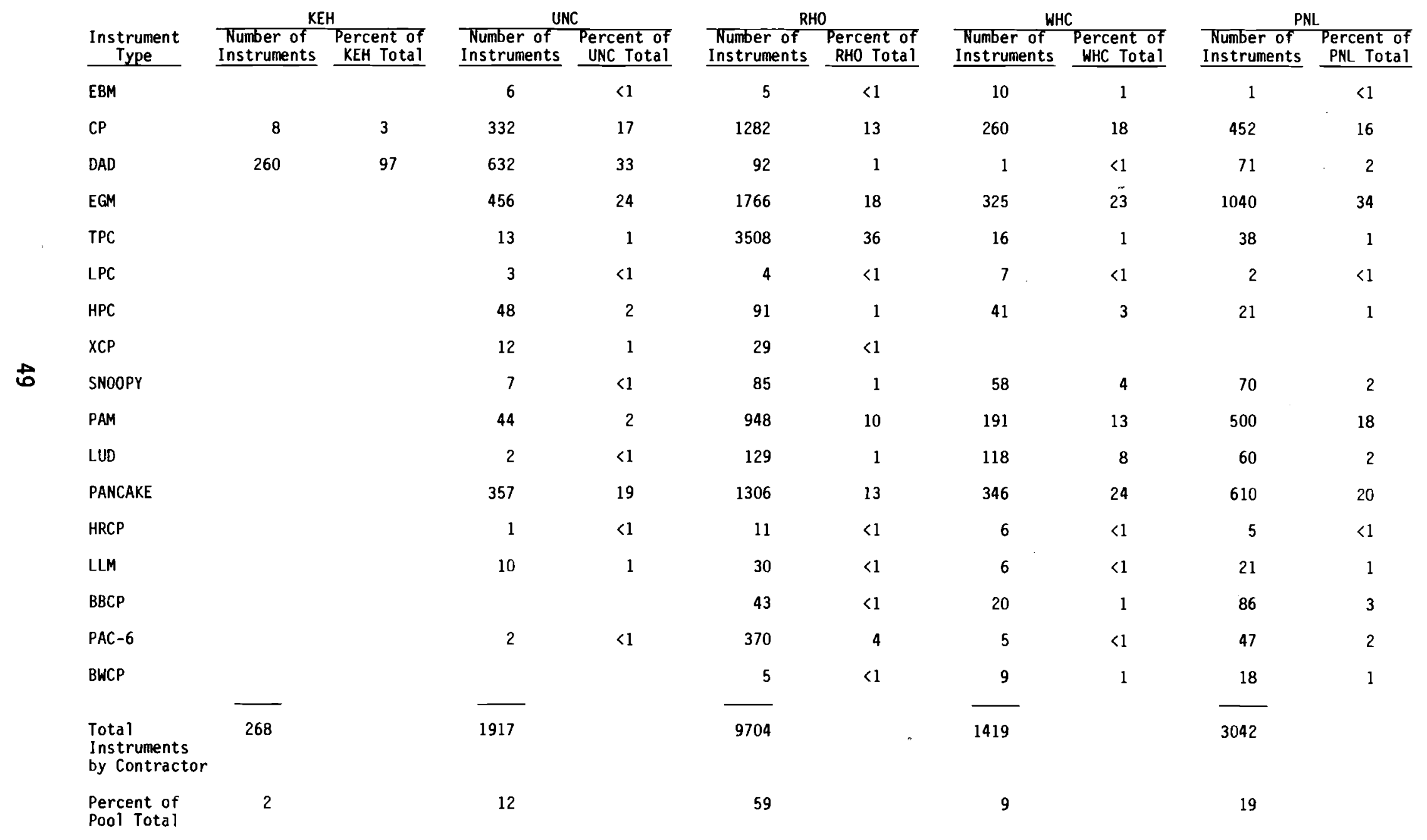




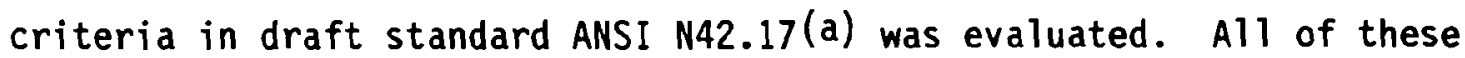
instruments were distributed to the field for evaluation except for the Victoreen Model 450s, which were found to be very sensitive to changes in temperature during the testing against ANSI N42.17 criteria and were sent back to the manufacturer to be exchanged for Model 450-Bs. A circuit change in the Model 450-B eliminated the temperature dependence problem.

During 1987 the Hanford Instrument Evaluation Committee completed the "Hanford Radioactive Contamination Release Survey Criteria." It received concurrence from all DOE-RL contractors. A copy of the document was sent to DOE-RL in answer to DOE-RL's request for a single uniform policy at Hanford.

\section{Deployment of High-Range CPS}

The High-Range CP (HRCP) is a pistol-shaped instrument with an airionization chamber used to measure high levels (up to $50 \mathrm{kR} / \mathrm{h}$ ) of beta and gamma radiation (see Figure 10). The HRCP Program milestones for 1987 included the completion of the upgrade of the FY 1985 instruments within 3 months of receipt of the new probe circuit boards, the completion of acceptance testing of the FY 1987 instruments within 3 months of their arrival, and delivery of the instruments to the field within 2 months of the completion of acceptance testing.

The FY 1987 instruments were received from Victoreen during the year, and the acceptance testing of these units was initiated. Problems with the software were worked on by the manufacturer throughout the year. A few units have been delivered to the field for use.

New probe circuit boards for the FY 1985 units were received, and the probe upgrade was initiated during the year.

The switches used on the instrument were evaluated, and a bezel was designed and fabricated to make the operation of the switches easier and more

(a) American National Standards Institute (ANSI). 1987. Performance Specifications for Health Physics Instrumentation - Portable Instrumentation for Use in Normal Environmental Conditions. Draft ANSI N42.17-D8, American National Standards Institute, New York, New York. 


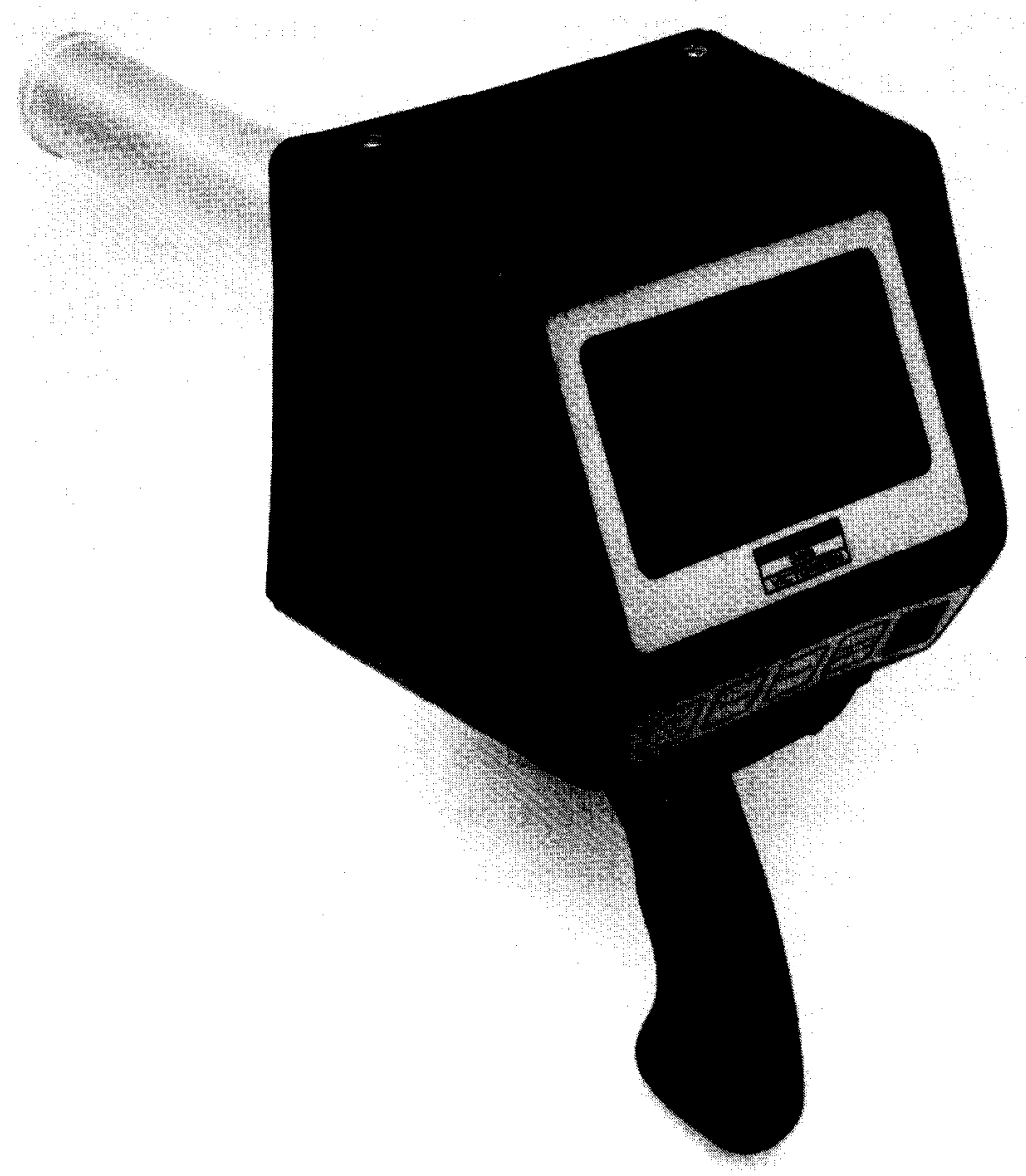

FIGURE 10. High-Range CP

reliable. Necessary parts were received, and improvements in the control switches have been initiated; some of this work will be continued as units are returned from the field for calibration or repair.

\section{Instrument Manual Update}

During 1987 correction factors for the HRCP were developed. These included geometrical factors for beta $(90 \mathrm{Sr} / 90 \mathrm{Y})$ and photon $(137 \mathrm{Cs})$ disk sources of varying sizes to be used with the two radiation detection chambers in the probe. These factors were added to the HRCP section in the Radiation 
Protection Instrument Manual.(a) Two new sections have been initiated for this manual for two different types of bench monitors: the Eberline Model RM-19 and Ludlum Model 177s.

Documentation of the History of Hanford Instruments

A report documenting the use and calibration of portable health physics instrumentation on the Hanford Site was initiated during 1987. It is scheduled to be prepared, reviewed, and published by the end of FY 1988. The report will review the early development and provide the historical background for the use of specific types of instrumentation and the calibration equipment and techniques used over the years of site operation.

SUPPORTING INVESTIGATION AND STUDIES

During 1987 the calibration procedure for the alpha continuous air monitor (CAM) was upgraded, the concept and final design for a $90 \mathrm{Sr} / 90 \mathrm{Y}$ beta source holder was developed, and the portable monitors for special nuclear material (SNM) were upgraded.

Upgrade of the Alpha CAM Calibration Procedures

Work was performed during 1987 on the upgrade of the alpha CAM calibration procedure for use as a sitewide procedure. Discussions were held with UNC, RHO, Hanford Engineering Development Laboratory (HEDL), and PNL personnel on the types of problems seen in the field, current calibration procedures and techniques, and the level of effort being spent on solving CAM problems. Specifically, the problem of the interference of radon, thoron, and their progeny in the measurement of 239pu with the current alpha CAMs was investigated. Extended air monitoring samples were obtained and analyzed for specific alpha energies associated with the natural background and the contribution of those energies to the plutonium energy interval. The feasibility of electronically changing the alarm set point during high-radon episodes is also being investigated in this study.

(a) Pacific Northwest Laboratory (PNL). 1982. Radiation Protection Instrument Manual. PNL-MA-562, Pacific Northwest Laboratory, Richland, Washington. 
Development of the Linear Beta Source Concept and Design

The concept and final design for a $90 \mathrm{Sr} / 90 \mathrm{Y}$ beta source holder to replace the "Fan Source" holder were developed by Instrumentation and External Dosimetry (I\&ED) personnel. The new source holders are safer than the fan sources; they are "spring loaded" and will automatically go to the safe position when not in use. Thirty holders were fabricated by PNL Craft Services for PNL, UNC, and an offsite DOE facility during the year. The sources were fabricated by HEDL personnel based on I\&ED specifications. Upgrade of the Special Nuclear Material Portable Monitors

The SNM portable monitors used in the field were upgraded. A literature search and contacts were completed with plant security and DOE security forces to identify standards and regulations concerning SNM monitor calibration. The required $1-\mathrm{g}-239 \mathrm{Pu}$ and $10 \mathrm{~g}-235 \mathrm{U}$ sources were procured for permanent use as calibration sources. The routine calibration procedure in PNL-MA-563(a) was revised and updated. The four different types of SNM monitors used at Hanford Site and two proposed types were evaluated for response. Several of these were evaluated in special field situations at different locations on the Hanford Site. Negotiations were completed with TSA Systems to upgrade their Model HHD-440 instruments for approximately one third the cost of new instruments. These will replace units purchased by Hanford Security personnel 5 years ago.

\section{PROGRAM-RELATED PROFESSIONAL MEMBERSHIPS}

The program-related professional memberships of the staff during 1987 are listed here.

- D. M. Fleming--Member of the Task Group 4 writing NCRP Handbook "Calibration of Survey Instruments for the Assessment of Ionizing Radiation Fields and Radioactive Surface Contamination" (NCRP-S.C.46)

(a) Pacific Northwest Laboratory (PNL). 1981. Radiological Calibration Procedures. PNL-MA-563, Pacific Northwest Laboratory, Richland, Washington. 
- D. M. Fleming--Member of the ANSI Working Group N42.17 writing the standard

- J. L. Kenoyer--Consultant to the ANSI Working Group N42.17 writing the standard

- J. L. Kenoyer--Member of the NSB-7 Working Group on the Calibration of Portable Health Physics Instruments.

- F. E. Owen--Member of the Working Group ANS/HPSSC ANSI 6.8 Standard "Area and Process Monitors." 
The Radiation Standards and Calibrations Project maintains radiological standards, special instrument and dosimeter response-characterizing equipment, and calibration data-handling equipment at Hanford. This activity provides the means to characterize response to various radiation fields encountered at Hanford and ensures that calibration fields are described in accordance with recommended standards and guides. This activity includes quality assurance responsibilities for routine calibration of instruments and dosimeters. The project routinely

- reviews calibration standards, regulations, and handbooks

- ensures that calibrations procedures used are in agreement with technically accepted methods

- maintains basic radioactive sources and instruments that serve as radiological standards

- provides traceability to the NBS

- maintains a data management system for instrument repair and calibration records.

Project activities conducted during 1987 are discussed in the following subsections.

ROUTINE PROGRAM

Two major functions comprise the project's routine program: maintenance of standards and capabilities and maintenance of the data management system. Maintenance of Standards and Capabilities

Various radioactive sources are used routinely for dosimeter and instrument calibrations. The "maintenance of standards" task provides for NBStraceable calibrations of the sources used in calibrating radiation-detection devices. Room 6 in the 318 Building houses a pneumatic source transfer and storage system, which contains $137 \mathrm{Cs}$ and $60 \mathrm{Co}$ photon sources and two levels of 252Cf neutron sources used for low-scatter irradiation geometries. The photon sources are calibrated periodically. Each source is measured in the 
most commonly used geometries. During 1987 agreement among the measurement data was within $\pm 2 \%$ of the values expected due to decay of the sources. Calibration checks of the 252Cf sources are performed by comparison with a plutonium-beryllium ( $\mathrm{Pu}-\mathrm{Be}$ ) source. Reference calibration data were collected in 1987 to allow the use of the free-field Pu-Be neutron spectrum as the source standard.

A high-level photon irradiator is housed in Room 8 of the 318 Building. The system consists of a highly shielded source-storage mechanism, a turntable for source selection, a closed-loop source-transport system, and a well-collimated irradiator with a conical beam port. The selected source is transported pneumatically to the irradiation position. An operational control panel is positioned outside the irradiation room and is well shielded against radiation exposure. A rail system is installed as a trolley support track over a 6-m range on the floor parallel to the beam axis. A laser centered on the beam axis is intersected by a cross laser at the $100-\mathrm{cm}$ distance to provide alignment capabilities. All four sources in the highlevel irradiator are calibrated annually. Measured exposure rates in 1987 were within tolerance of the values (2\%) expected due to decay of the sources. The calibration measurements are performed using measurement and test equipment that have certified traceability to the NBS.

Four wells containing isotopic sources are housed in Room 121 of the 318 Building. These wells are used primarily in the routine calibration program for portable instruments. Computer programs are used to control a trolley system that moves the source vertically to any desired point within the 9-m depth, based on calibration of the wells. The programs allow for selection of either desired exposure or dose-equivalent rate or distance with known rate. The program is also capable of stepping through the exposure rate points of the desired instrument calibration with only minimal operator involvement. The distance from the plane of the well's surface to the detector center is entered as an offset and is included in the selected overall distance. All wells receive extensive annual calibration in addition to the less extensive quarterly calibration checks that are directly related to routinely used instrument calibration points. No unusual variances were 
observed from the expected decay of source emissions due to isotopic halflives in 1987.

Improvements to the Maintenance of Standards and Calibrations Functions

In Room 6, a new 60 Co source that was installed in the pneumatic sourcetransfer system was calibrated, and an improved calibration protocol was developed for the Model NP-2 neutron-measuring instruments (SNOOPYs). The 60 Co source allows for greater flexibility in dose rates and photon energies when performing high-level irradiations. The revised protocol for the

SNOOPYs ensures that the effects of room-return and the ingrowth of 241 Am are taken into account during calibration.

In Room 121, an attenuator mechanism for photon source well 3 was designed, constructed, and installed. The new attenuator will increase the dynamic range of the well. Calibrations were carried out to verify the expected attenuation of the device.

Maintenance of the Data Management System

Maintenance and updating of the process-control system, including the Hewlett Packard (HP)-9000 computer, its peripherals, and the data management software comprise the data management system. Several system improvements were made during 1987.

Improvements to the Maintenance of the Data Management System Function

The HP-1000 computer was replaced by an HP-9000 that was moved into a new facility in the 318 Building. The new computer has greatly increased speed and storage capability. The choice of an HP machine allowed for compatibility with our existing terminals and peripherals. The HP-9000 is also identical to three other machines currently in use in the Health Physics Department, and this will allow establishment of a local area network. Three HP terminals were also bought and installed in two rooms and the instrument shop.

The software service contract was maintained with HP throughout the year, which kept the HP-1000 software current until the machine was replaced. A similar contract is now in place for the HP-9000. Software updates were installed as received. The advanced graphics package, GRAFIT, was purchased 
for use on the HP-9000. The calibration database was transferred to the HP-9000 ahead of schedule. Changes were made to the calibration support programs MAIN and STATS so that they could run on the HP-9000. Several software programs were written or modified in-house during the year. A program was prepared to permit data input to the instrument database through a form on the terminal screen, and to permit modifications to the software needed for computer-generated billing of calibration charges. The instrument database was also upgraded with modified software.

\section{SUPPORTING INVESTIGATIONS AND STUDIES}

Several special studies were performed to help improve the quality assurance programs for dosimeter and instrument calibrations.

Measurement Quality Assurance for Photon Beams and $90 \mathrm{Sr}$ Beta Sources

Interaction with NBS for measurement quality assurance (MQA) of photon beams and $90 \mathrm{Sr}$ beta sources demonstrated the consistency of these sources with national standards. The purpose of MQA testing is to ensure on a continuing basis that the total measurement uncertainty, relative to an accepted national standard, of a particular procedure is known. In our case, agreement to within $2 \%$ of the national standard is considered acceptable. For photon beams, the NBS reported excellent agreement $(<2 \%)$ except for the H150 beam, whose calibration factor was out of agreement by $4 \%$. This increased uncertainty for the $\mathrm{H} 150$ beam was found to be due to improper filter whee? positioning. Hardware modifications were made to bring this beam to within $2 \%$ agreement with the NBS. The MQA of our $90 \mathrm{Sr}$ beta sources was accomplished at PNL by Jack Pruitt of the NBS. The comparison showed consistency between PNL and NBS to within $2 \%$.

Intercomparison of K-Fluorescence Standards

An intercomparison was carried out between PNL and the National Radiological Protection Board (NRPB) of England, to cross check our k-fluorescence $x$-ray standards. Calibration of these sources is not possible at the NBS. The study showed consistency between PNL and NRPB to within $2 \%$. 
Source Travel Time Study

A source travel time study was carried out for both the North and South stations of the low-scatter room. It was concluded that for irradiations of less than two minutes, the effect of the source travelling time cannot be neglected. Therefore, a correction for source travel time must be made for short irradiations.

Plutonium-Lithium Source Calibration

The plutonium-lithium ( $P u-L i$ ) source emits a neutron spectrum lower in energy than either $252 \mathrm{Cf}$ or $\mathrm{Pu}-\mathrm{Be}$, and provides an additional energy value for response studies of neutron instruments. The Pu-Li neutron source in the low-scatter room of the 318 Building was calibrated using a tissue-equivalent proportional counter. Due to the need for further improvements in the interlock system, the source remains locked out of use. Work on this system will resume in 1988.

Evaluation of Instrument Bar Code Labels

A pilot test was carried out to evaluate the possibility of using bar code labels on instruments that could be automatically entered into the computer. The instruments that were so coded survived field use with readable labels. The possibility of putting this system into routine use will be investigated during 1988. 


\section{HANFORD RADIOLOGICAL RECORDS PROGRAM}

The Hanford Radiological Records Program supports the radiation protection programs of the DOE-RL and its contractors by administering and preserving radiological exposure records for all Hanford workers and visitors, past and present. The Program also is responsible for the Hanford Radiation Protection Historical Files, which include documents such as policies, procedures, reports, important comnunications, etc., that define the radiological dosimetry and protection programs during Hanford's history.

The ORE system, which includes a database with the personnel exposure records that are readily retrievable, is an integral part of the records program. The ORE system also includes all of the supporting exposure documentation on microfilm, which is indexed into a computer-assisted retrieval (CAR) system. The CAR system allows for rapid retrieval of the documents for any individual using identifiers including payroll number, social security number, and/or name. The computer systems and equipment necessary to input, store, and retrieve the records and produce the required reports are operated by the program personnel.

The program is operated under the applicable sections of ANSI Standard N13.6-1972 (ANSI 1972), DOE 1300.1 (DOE 1980a), DOE 1324.2 (DOE 1980b), DOE 5480.1 (DOE 1981a), draft DOE 5480.11, (a) and DOE 5484.1 (DOE 1981b with June 1987 change) as assigned by the Hanford Site Services Handbook (RL 1983). It also complies with the applicable sections of the Privacy Act (1974).

The 1987 Program activities are discussed in the following subsections.

\section{ROUTINE PROGRAM}

The Hanford Radiological Records Program consists of three major functional areas: data handling, report issuance, and the library. The datahandling function provides for the entry of data elements into the ORE database and for the validation of all data entered. Validation is accomplished

(a) U.S. Department of Energy (DOE). 1987. Radiation Protection for Occupational Workers. Draft DOE 5480.11, U.S. Department of Energy, Washington, D.C. 
by establishing audits to be matched to entries of results, resolving unmatched results, and communicating with contractor personnel when resolution requires investigation or other field information.

The report issuance function generates and issues routine reports to the contractors, quarterly man-rem and annual statistical reports to DOE, annual reports to employees, and special reports requested by former employees, contractors, and DOE-RL. This function maintains close liaison with DOE-RL, contractors, and other personnel dosimetry functions.

The library function maintains the individual exposure records that are not reducible to database elements and the Hanford Radiation Protection Historical files. The records staff file and retrieve current hard-copy documents, prepare documents for long-term storage, and track and account for the documents through the microfilming and indexing process. The library contains the individual exposure records since 1945 (over three million microforms). These and the historical file microforms are retrievable through two CAR systems that are maintained by the library staff.

Although the results for the dosimeter and excreta processing and for the in vivo counts are received by electronic transmission or magnetic tape, a large amount of data that is needed in the records is received by hardcopy form. These data are handled manually. Table 12 presents statistical information on many of the documents that are entered into the database and microfilmed and indexed into the CAR system.

Changes to the Routine Program

Special processing forms and quality control provisions were added to the routine program during 1987.

Special Processing Forms

Starting in 1987, special dosimeter processing forms are included in the applicable individual's records in the ORE system. Prior to 1987, these records were sent to the National Archives. Because many of these forms were 
TABLE 12. Records Activity for Calendar Year 1987

Document

Number

Personal Radiation Exposure History form (used to

3,789 document exposure history prior to Hanford)

Employee and Dosimetry Change forms (used to document

personnel or dosimetry changes)

Employee and Dosimetry Change forms (used to document 3,926

employee terminations)

Temporary Dosimeter Assignment forms (used for

visitors and employees who forgot their dosimeters)

20,948

Investigation of Dosimeter Result forms (used to

1,691

estimate exposure for lost, damaged, or otherwise

suspect dosimeter results)

Special Process Forms (used to document data for specially processed dosimeters)

3,627

Training Documents (used to document radiological

training of personnel)

14,196

Request for Special Excreta Sample Analyses (used to

1,666

- initiate the collection of samples for analysis)

Offsite Requests for Exposure Summaries (responses

to requests for ex-Hanford employees radiation exposures)

Letters Sent to Request Prior Exposure (used to request radiation exposure summaries for new employees with previous exposure)

Microfilm Reels Indexed into the CAR System (personnel and historical documents; each reel contains over 2200 images)

being recalled, the change results in more efficient retrieval of the forms when needed. The forms issued prior to 1987 are still in the National Archives and will not be returned at this time. This has significantly increased the effort in the library because there were over 7000 special processings during 1987. 


\section{Quality Control Provisions}

An extensive effort was made in 1987 to evaluate and document the QC provisions in the records program. Flow charts were developed for all forms that are processed in the ORE system, as well as certain specific functions, to identify the built-in QC checks and to determine where additional checks were needed. These flow charts, with explanatory text, will be included in the Internal Working Procedures Manual for Radiological Records during a 1988 revision.

\section{SUPPORTING TASKS}

Several tasks were completed to improve the ORE system or make modifications to meet changing needs, especially in response to Hanford contractor consolidation. A new committee was formed to study the ORE system and other dosimetry computer systems to determine how to make them more effective and enhance the radiological protection of the workers.

\section{Changes Made to Accommodate Hanford Contractor Consolidation}

The Hanford contractors were consolidated during 1987. The JAJ personnel were consolidated with KEH in March 1987. The majority of the RHO and UNC personnel were consolidated with WHC, and BCSR became affiliated with WHC. The latter moves were made in July.

The consolidation had a major impact on the Hanford Radiological Records Program due to the changes in payroll numbers, company codes, and organizational codes that are all important to the ORE system.

Some specific actions that took place with this consolidation include the following:

- Al1 companies assumed the ORE records of the previous contractor $(s)$.

- Letters were written giving permission for the new contractors to have early access to the exposure records.

- New company codes were assigned for the new contractors.

- A new payroll number was established for all new hires to the Hanford Site by WHC. Rockwell Hanford Company, UNC, and BCSR 
employees who transferred to WHC retained their former payroll numbers. Any WHC, RHO, UNC, or BCSR employees who transferred to PNL were given PNL payroll numbers. Kaiser Engineers Hanford accepted the JAJ payroll numbers.

- A letter of transfer was placed in each individual employee's occupational exposure file.

- Copies of all important letters, memos, and lists regarding the consolidation were placed in the Hanford Radiation Protection Historical Files.

- New ORE passwords were assigned to all personnel needing access to computer records; those passwords no longer needed were erased.

- New organizational codes were established by DOE.

- Al1 computer programs were revised to reflect the changes.

- It was agreed that dosimeters would not be exchanged until the previously scheduled date. This eliminated an unusually large special processing of dosimeters.

Some important aspects to be considered for future consolidations or diversifications to reduce many of the problems encountered include the following:

- Radiological Records needs to become involved in the planning at the beginning.

- Radiological Records needs to have input into the assignment of new or different payroll numbers and company codes, because the computer records system is based on these.

- To reduce the many problems resulting from computer program changes, it is advisable to consolidate all items at the same time (i.e., do not change company codes on one date and organization codes on another, as was done). 
Modifications to the ORE System--Specific Body Locations

and New Dosimeter Types

To accommodate the use of multiple dosimeters by contractor radiation protection groups, a file was established where supplemental dosimeter results could be entered with the results keyed to a specific body location. These results are not entered into the individual's exposure record. The contractor radiation protection representative reviews the results and, if a change in the dose is required, sends a letter to request that the change be made by ORE data entry.

The ORE system was also modified to incorporate the new beta-photon and two-element dosimeters. These results are also placed in a supplemental file. If the results are to be entered into an individual's record, the applicable contractor sends a letter to request that the change be made by ORE data entry.

\section{Hanford Dosimetry Computer Integration Committee}

An ORE users group was formed to provide long-range planning for dosimetry computer systems such as the proposed redevelopment of the ORE system and local area network integration, to define the purpose of the ORE system and its relationship to other dosimetry systems, and to establish dosimetry computer priorities. The committee includes all major users of the ORE system and representatives from the ORE system and DOE-RL. A charter has been approved, and the committee has started studying the existing systems. The minutes of the committee meetings are preserved in the Hanford Radiation Protection Historical Files. 


\section{REFERENCES}

American National Standards Institute (ANSI). 1972. Practice for Occupational Radiation Exposure Records Systems. ANSI N13.6-1972, American National Standards Institute, New York, New York.

American National Standards Institute (ANSI). 1976. American National Standard for Personnel Neutron Dosimeters (Neutron Energies Less Than $20 \mathrm{MeV}$ ). ANSI N319-1976, American National Standards Institute, New York, New York.

American National Standards Institute (ANSI). 1978. Radiation Protection Instrumentation Test and Calibration. ANSI N323-1978, American National Standards Institute, New York, New York.

American Nuclear Society. 1987. "Low Rad Limits on Food to Continue into 1988." Nuclear News, January 1987, p. 63.

Dolphin, G. W., and I. S. Eve. 1963. "Some Aspects of Radiostrontium Dosimetry." Phys. Med. Biol. 8(2):193-203.

Hu11, A. P. 1987. "Chernobyl Deposition Apparent in Some U.S. Whole Body Counts." In Health Physics Society Newsletter. XV(12)18.

International Commission on Radiological Protection (ICRP). 1959. Report of Committee II on Permissible Dose for Internal Radiation. Publication 2, Pergamon Press, New York, New York. •

International Commission on Radiological Protection (ICRP). 1979. Limits for Intakes of Radionuclides by Workers. Publication 30, Part 1 and Supplement, Pergamon Press, New York, New York.

Johnson, J. R., and M. B. Carver. 1981. "A General Model for Use in Internal Dosimetry." Health Phys. 40:341-348.

Jones, S. R. 1985. "Derivation and Validation of a Urinary Excretion Function for Plutonium Applicable Over Tens of Years Post Intake." Rad. Prot. Dos. $11(1): 19-27$.

McInroy, J. F., M. A. Boyd, C. C. Eutsler, and D. Romera. 1983. "The U.S. Transuranium Registry Report on the 241 Am Content of a Whole Body--Part IV: Preparation and Analysis of the Tissue and Bone." Health Phys. 45:847-853.

Privacy Act, 44 Fed. Reg. 510772 (1974).

Rathbun, L. A. 1987. "Penetrating Radiation Monitoring." In Environmental Monitoring at Hanford for 1987. PNL-6464, Section 3.7, Pacific Northwest Laboratory, Richland, Washington. 
Traub, R. J., W. D. Reece, R. I. Scherpelz, and L. A. Sigalla. 1987. Dose Calculation for Contamination of the Skin Using the Computer Code VARSKIN. NUREG/CR-4418, PNL-5610, Pacific Northwest Laboratory, Richland, Washington.

U.S. Department of Energy (DOE). 1980a. Micrographics Management. DOE 1300.1, U.S. Department of Energy, Washington, D.C.

U.S. Department of Energy (DOE). 1980b. Records Disposition. DOE 1324.2, U.S. Department of Energy, Washington, D.C.

U.S. Department of Energy (DOE). 1981a. Environmental Protection, Safety, and Health Protection Program for DOE Operations. DOE 5480.1, U.S. Department of Energy, Washington, D.C.

U.S. Department of Energy (DOE). 1981b. Environmental Protection, Safety, and Health Protection Information Reporting Requirements. DOE 5484.1, U.S. Department of Energy, Washington, D.C.

U.S. Department of Energy (DOE), Richland Operations Office. 1986. Requirements for Radiation Protection. RL 5480.11A, U.S. Department of EnergyRichland Operations Office, Richland, Washington.

U.S. Department of Energy (DOE). 1987. Department of Energy Laboratory Accreditation Program for Personnel Dosimetry. DOE 5480.15, U.S. Department of Energy, Washington, D.C.

U.S. Department of Energy-Richland Operations Office (DOE-RL). 1983. Hanford Site Services Handbook. RLPI 9-50.5, U.S. Department of EnergyRichland Operations Office, Richland, Washington. 


\section{$\underline{\text { DISTRIBUTION }}$}

No. of

Copies

OFFSITE

2 DOE/Office of Scientific and Technical Information

\section{ONSITE}

5 DOE Richland Operations Office

E. A. Erichsen

D. T. Evans

J. R. Patterson

D. L. Sours

G. R. Yesberger

Hanford Environmental Health Foundation

B. D. Breitenstein

Kaiser Engineers Hanford

D. J. Foust

2 Westinghouse Hanford Company

R. 0. Budd

W. A. Decker, Jr.
No. of

Copies

40 Pacific Northwest Laboratory

W. J. Bair

L. G. Faust

J. J. Fix (2)

D. P. Higby

G. R. Hoenes

J. R. Houston

J. R. Johnson

J. L. Kenoyer (2)

J. A. Leonowich (2)

M. Lyon (10)

J. B. Martin

J. C. McDonald

I. C. Nelson, Sr.

H. E. Palmer (2)

J. M. Selby

K. L. Soldat

M. J. Sula (2)

Publishing Coordination (2)

Technical Report Files (5)

Radiation Protection Historical

Files (c/o V. L. Berndt) (2) 